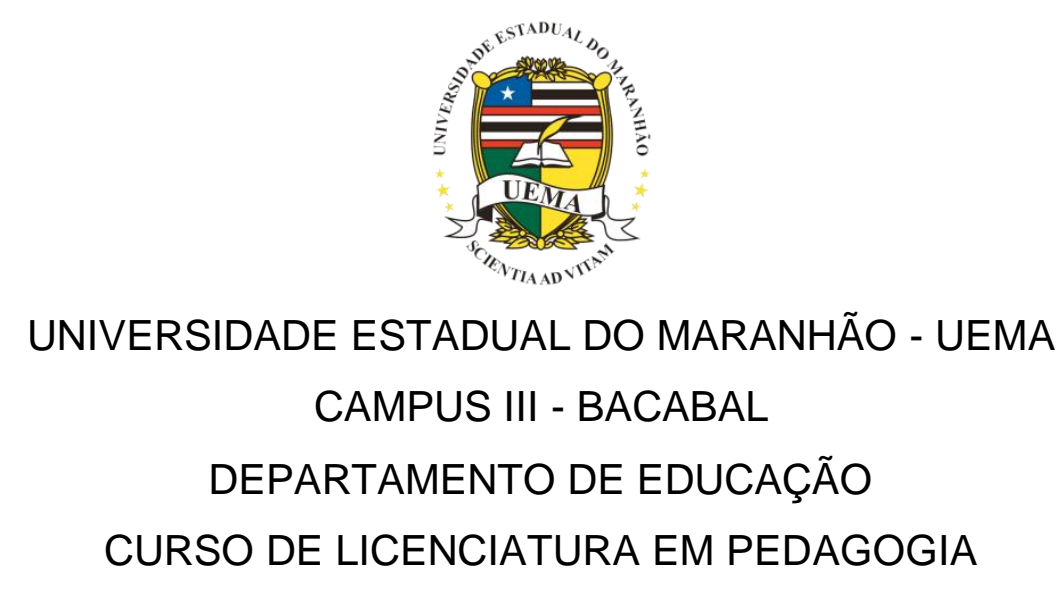

ÉRICA CRISTINA FRAZÃO DE MOURA

LAISE KATIANE ALENCAR LIMA

A INSERÇÃO DAS TECNOLOGIAS DE INFORMAÇÃO E COMUNICAÇÃO NA APRENDIZAGEM DO ENSINO DE HISTÓRIA DOS ALUNOS DA U.E.F. BALBINA CARVALHO, MUNICÍPIO DE BACABAL-MA

BACABAL 
ÉRICA CRISTINA FRAZÃO DE MOURA

LAISE KATIANE ALENCAR LIMA

\title{
A INSERÇÃO DAS TECNOLOGIAS DE INFORMAÇÃO E COMUNICAÇÃO NA APRENDIZAGEM DO ENSINO DE HISTÓRIA DOS ALUNOS DA U.E.F. BALBINA CARVALHO, MUNICÍPIO DE BACABAL-MA
}

\author{
Trabalho de conclusão de curso apresentado à \\ Universidade Estadual do Maranhão - UEMA, \\ Campus III - Bacabal como requisito para \\ obtenção do grau de Licenciatura Plena em \\ Pedagogia.
}

Orientador: Prof. Msc. Nágela Mary Lima

BACABAL 


\title{
ÉRICA CRISTINA FRAZÃO DE MOURA
}

\section{LAISE KATIANE ALENCAR LIMA}

\section{A INSERÇÃO DAS TECNOLOGIAS DE INFORMAÇÃO E COMUNICAÇÃO NA APRENDIZAGEM DO ENSINO DE HISTÓRIA DOS ALUNOS DA U.E.F. BALBINA CARVALHO, MUNICÍPIO DE BACABAL-MA}

\author{
Trabalho de conclusão de curso apresentado à \\ Universidade Estadual do Maranhão - UEMA, \\ Campus III - Bacabal como requisito para \\ obtenção do grau de Licenciatura Plena em \\ Pedagogia.
}

Aprovado em:

Nota:

BANCA EXAMINADORA

\author{
Prof. Msc. Nágela Mary Lima \\ UEMA / Campus III - Bacabal \\ Orientador
}

1ํㅡㄹ. Examinador

2ํㅡㄹ Examinador 
A Deus, o grande maestro das nossas vidas.

Aos nossos pais: Cristiane Oliveira Frazão, Kátia Alencar Lima, Maria Pereira de Oliveira, Leomar Silva Lima e Sebastião Paulino dos Santos por serem alicerces de força e amor em todos os momentos.

Aos nossos irmãos: Laryssa Katiane Alencar Lima e Raimundo Nonato Oliveira Frazão pela motivação diária e auxílios constantes.

E a uma pessoa que mesmo sendo de pouca idade nos propicia a luz necessária, através de sua doçura, inspiração e encanto extraordinário: nosso Luiz Emanoel Lima Cutrim. 


\section{AGRADECIMENTOS}

Agradecemos a Deus, luz substancial que nos envolveu com seu amor para conseguirmos enfrentar os entraves que permearam nossa trajetória, e a todo vigor que este nos ejeta corriqueiramente.

Às nossas famílias, que em todo percurso nos dispôs o ímpeto necessário para alcançar mais essa conquista, em especial nossas mães que, com histórias de vidas semelhantes de trabalho árduo e estudo, onde o foco principal sempre fora o encaminhamento dos filhos, tanto na vida pessoal como profissional, ocuparam o centro dos nossos melhores exemplos de determinação e persistência para desfrute de um mundo melhor.

À nossa orientadora Msc. Nágela Mary Lima, que com toda a sua experiência, paciência, bons conselhos e desenvoltura nos desencadeou na referida produção.

À nossa parceria, que desde o início do curso regeu-se pela reciprocidade e gratidão e que se estendeu para a vida, onde podemos lograr mais esse triunfo, subsidiadas pela amizade, respeito, irmandade e admiração que tecemos uma pela outra.

Aos nossos professores de curso que, com todos os seus conhecimentos, nos promoveram saberes imprescindíveis.

Aos nossos colegas de turma, que nos propuseram compreender a importância do exercício do relacionamento com o outro.

Aos nossos amigos, que albergaram nossas ausências, e que nos direcionaram com palavras de afago e descontração quando os obstáculos se fizeram presente.

E a todos que de alguma forma participaram desse momento sublime e incomensurável de nossas existências. 
"Não se amoldem ao padrão deste mundo, mas transformem-se pela renovação da sua mente, para que sejam capazes de experimentar e comprovar a boa, agradável e perfeita vontade de Deus." (Romanos, 12:2). 


\section{RESUMO}

O presente estudo objetiva Socializar as Tecnologias de Informação e comunicação na aprendizagem do ensino de história dos alunos da U.E.F. Balbina Carvalho. O embasamento teórico subsidiou-se a partir de pesquisas em bibliografias de autores como: Pischetola (2016), Moran (2015), Braga (2013), os quais relatam que a disciplina enfatizada necessita munir-se de ferramentas tecnológicas capazes de contribuir para o dinamismo e interatividade dos conteúdos tecidos. Para consumação desse trabalho, norteou-se na metodologia da pesquisa quanto aos seus objetivos, na pesquisa exploratório-descritiva e pesquisa bibliográfica, de natureza quali-quantitativa. Aplicando como instrumentos de coleta de dados, a observação sistemática e participante, o questionário, a pesquisa bibliográfica e a pesquisa-ação. Notando assim, a relevância que a utilização dos recursos tecnológicos nas aulas de história, promovem saberes imprescindíveis e transformadores, com a aplicabilidade social necessária na vida dos alunos.

Palavras-chave: Tecnologias. História. Informação. Comunicação. 


\begin{abstract}
The present study aimed to be socialized as Information and Communication Technologies in the teaching of the history of U.E.F. students Balbina Carvalho. Theoretical basis subsidized from bibliographies of authors such as: Pischetola (2016), Moran (2015), Braga (2013), which relate to the subtask of providing technical tools capable of contributing to the dynamism and interactivity of visible tissues. For the consummation of the work, North American in the methodology of a research with its objectives, exploratory-descriptive research and bibliographical research, of qualitative-quantitative nature. Applying the instruments of data collection, a systematic analysis and participation, the questionnaire, bibliographic research and action research. Noting thus, once the use of technological resources in history classes, the promotion of printed and transformational knowledge, with a necessary social application in the lives of students.
\end{abstract}

Keywords: Technologies. Story. Information. Communication 


\section{LISTA DE ABREVIATURAS E SIGLAS}

TICS Tecnologia de Informação e Comunicação

PCS Personal Computer

CDS Compact Disc

DVDS Digital Versatile Disc

WIFI Wireless Fidelity

RFID Radio Frequency Identification

NTIA National Telecommunications and Informations Administration

APPS Application

PCN Parâmetros Curriculares Nacionais

TCLE Termo de Consentimento Livre e Esclarecido

ECA Estatuto da Criança e do Adolescente

SEMED Secretaria Municipal De Educação

UEF Unidade De Ensino Fundamental

PPP Projeto Político Pedagógico 


\section{LISTA DE GRÁFICOS}

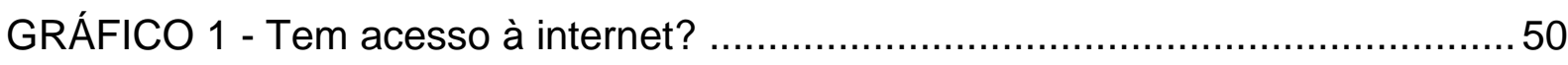

GRÁFICO 2 - Que meios você utiliza para esse acesso? ......................................51

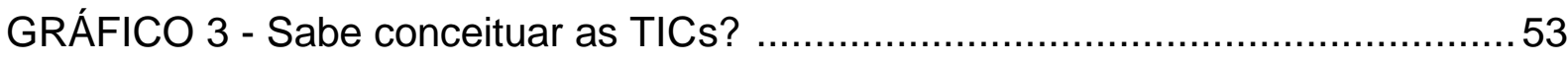

GRÁFICO 4 - A professora utiliza as TICs nas aulas de história? ..........................54

GRÁFICO 5 - Os conteúdos de história tornam-se mais claros quando se utilizam

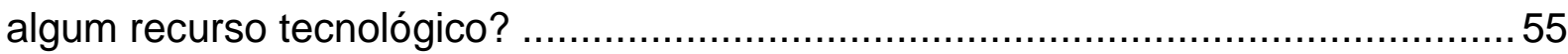

GRÁFICO 6 - Quando a professora solicita a pesquisa de temas de história recorre à internet?

GRÁFICO 7 - Se utiliza a internet, limita-se apenas o primeiro site para finalizar a pesquisa?

GRÁFICO 8 - Costuma assistir vídeos, músicas, filmes, novelas sobre os conteúdos de história?

GRÁFICO 9 - A professora utiliza o laboratório de informática nas aulas de história?

GRÁFICO 10 - Antes do projeto a inserção das TICs na aprendizagem de história, já havia escutado ou lido sobre as TICs?

GRÁFICO 11 - As aulas com o uso das TICs proporcionadas pelo projeto deixaram as aulas de história mais prazerosas?

GRÁFICO 12 - As TICs nas aulas de história facilitam uma apreensão mais ampla dos conteúdos tratados em sala de aula? 62 GRÁFICO 13 - Utilizam as TICs para revisar ou complementar os conteúdos de história após o projeto? 63 
1 INTRODUÇÃO

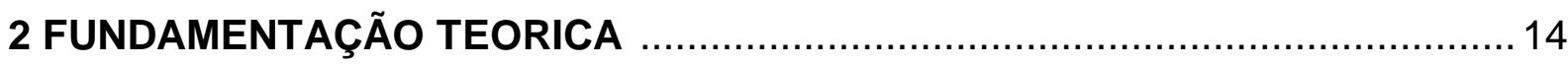

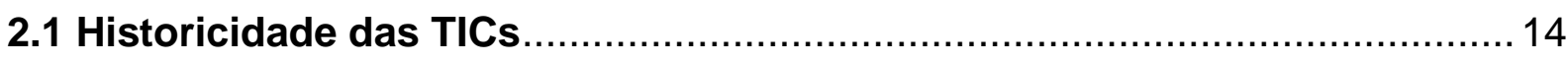

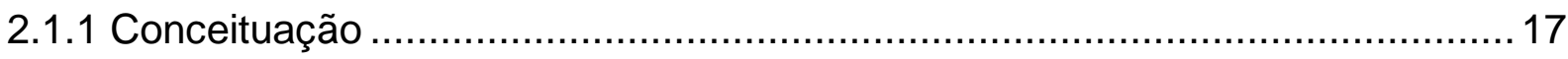

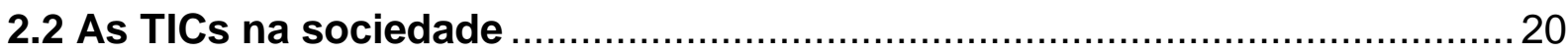

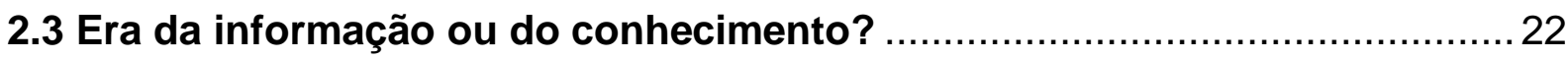

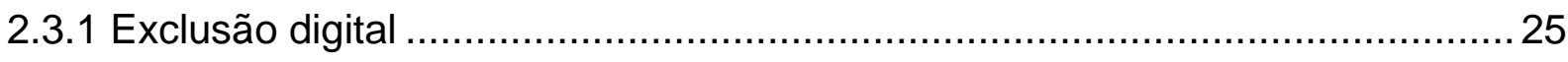

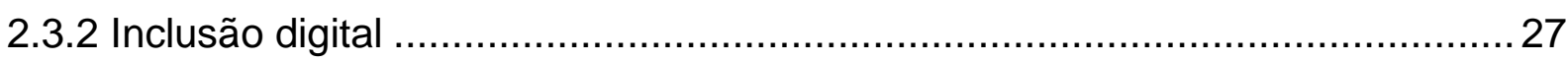

3 AS TICS COMO FERRAMENTAS DE APRENDIZAGEM DO ENSINO DE

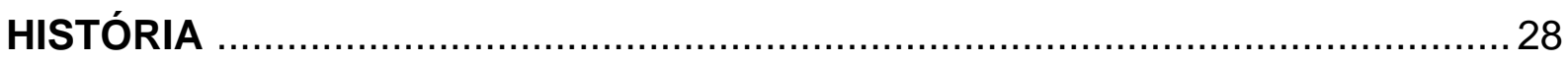

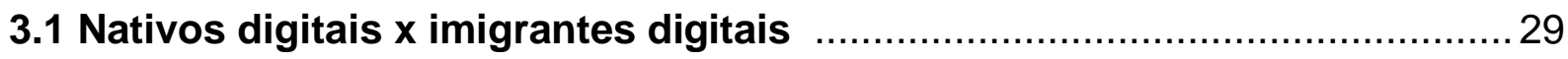

3.2 Navegar é necessário: história contextualizada ........................................ 32

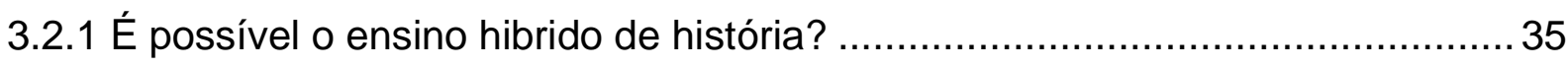

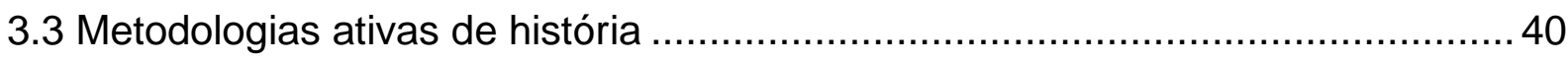

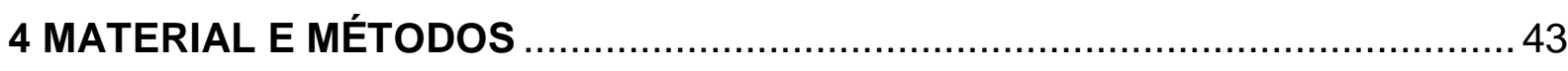

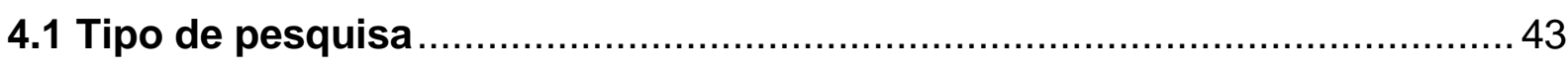

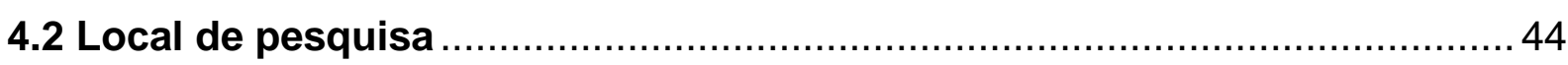

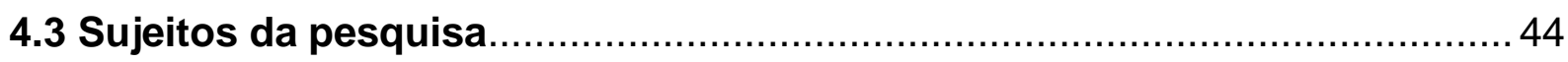

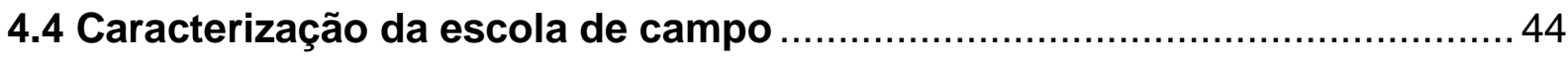

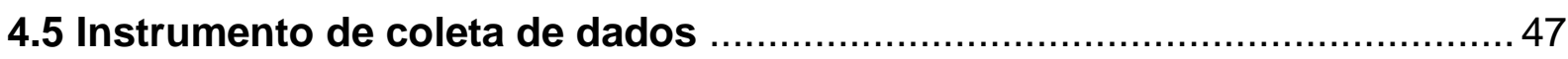

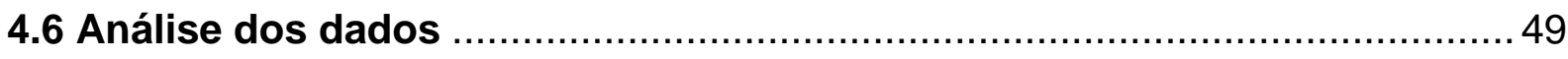

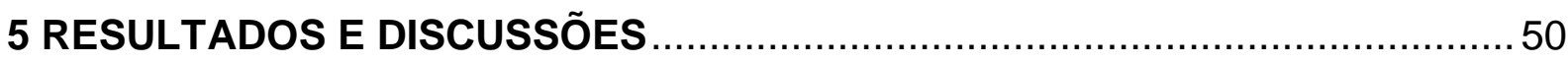

6 PROPOSTA

6.1 A INSERÇÃO DAS TECNOLOGIAS DE INFORMAÇÃO E COMUNICAÇÃO NA APRENDIZAGEM DO ENSINO DE HISTÓRIA DOS ALUNOS DA U.E.F. BALBINA

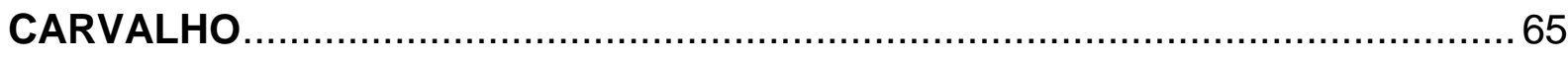

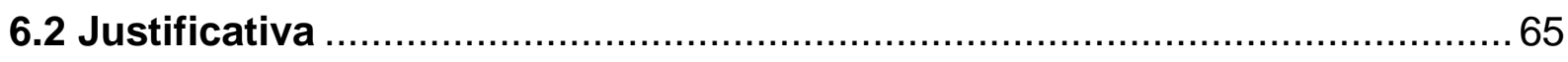

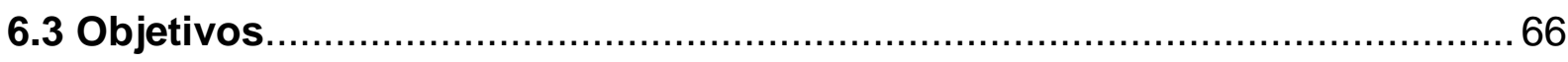

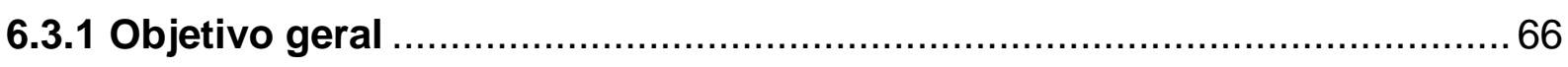

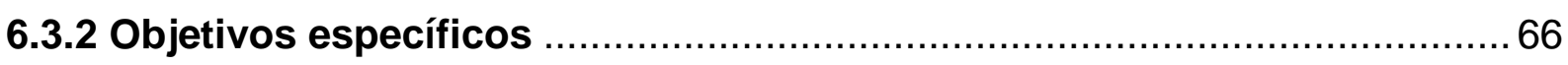

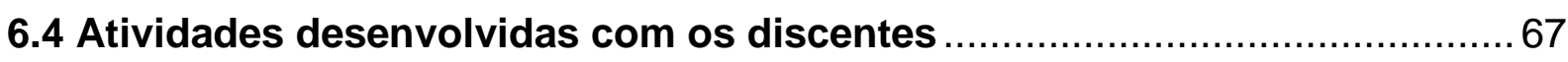

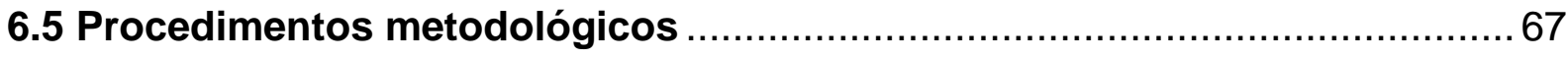




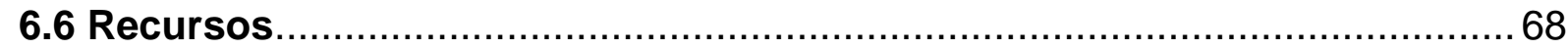

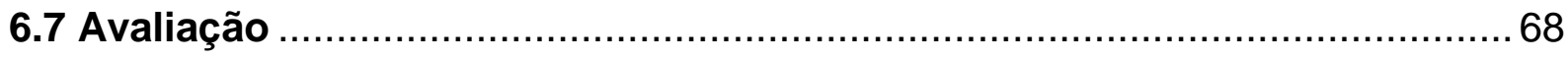

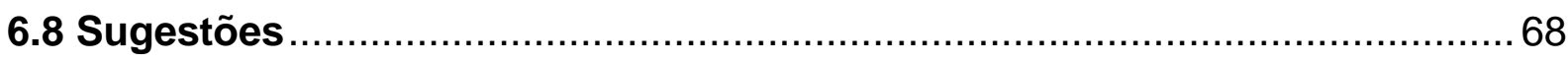

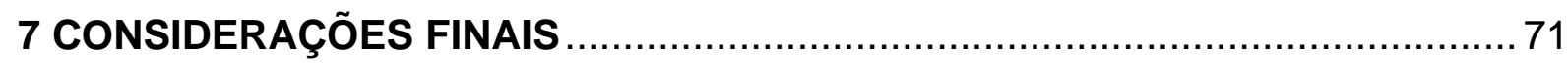

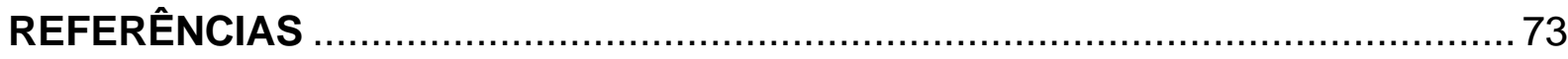

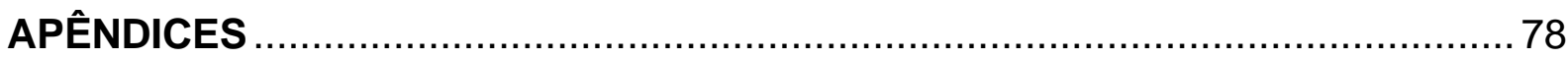

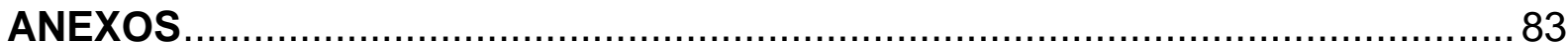




\section{INTRODUÇÃO}

As Tecnologias de Informação e Comunicação (TICs) eram utilizadas com finalidades específicas e restritas no âmbito escolar, uma vez que, serviam apenas para informatizar as tarefas de ordem administrativa, financeira, no que tange a matrícula, histórico e demais conjunturas escolares. As mesmas foram inseridas sem conexões diretas com a parte pedagógica. Contudo, atualmente, não se pode mencionar a Educação sem adentrar nos papéis expressivos que as mesmas possuem na transmissão de saberes e desse novo dinamismo que a sala de aula necessita, tornando os alunos motivados a interagir com os conteúdos de história difundidos.

Levando em consideração tais anseios, percebe-se que o estudo em questão se justifica para estabelecer pontos entre tais ferramentas e o ensino de história, visto que, ainda são perceptíveis inúmeras aulas monótonas, onde o livro didático é o único apoio pedagógico para lecionamento. Aulas essas, onde os alunos permanecem em seus assentos transcrevendo do quadro, textos, juntamente com os exercícios, tornando-os reféns da repetição e memorização de datas, em detrimento de contextualizar fatos e ressignificar conteúdos, através do uso de dispositivos tecnológicos que a própria escola oferece.

Ressalta-se ainda que, nem de longe os recursos que a escola possui eram aproveitados na sala de aula em estudo. Quando estes começaram a ser explorados a partir de sua terminologia TICs,causaram nos educandos, curiosidades e entusiasmos, haja visto que, até então não tinham contato com tais ferramentas na escola, somente em suas casas, mas que seu uso se limitava apenas a diversão e entretenimento.

Diante dessa abordagem que a tecnologia estabelece, tornou-se imprescindível discorrer sobre tais ferramentas na Educação, de forma mais especifica, na inserção das TICs na aprendizagem de história do $5^{\circ}$ ano da Unidade de Ensino Fundamental Balbina Carvalho, situada no município de BacabalMaranhão.

O Objetivo geral do estudo alicerça- se em analisar as Tecnologias de Informação e comunicação na aprendizagem do ensino de história dos alunos da U.E.F. Balbina Carvalho. Desse modo, em todo percurso almejou-se: esclarecer conceitos e entendimentos sobre as TICs na sociedade e na Educação; identificar 
como as TICs estão sendo abordadas nos conteúdos de história; apontar os principais desafios enfrentados pelos discentes para que as TICs contemplem suas vivências pedagógicas no ensino de história; sugerir a utilização de dispositivos tecnológicos e suas mídias para a dinamização no ensino de história.

De acordo com os pressupostos da referida pesquisa a proposta estruturouse da seguinte forma:

No primeiro capitulo é regida a introdução, na qual retrata de modo sucinto o tema proposto, os objetivos e a metodologia da pesquisa.

No segundo capitulo é discorrido acerca da historicidade das TICs, onde são mencionadas conjecturas de conceituação dessas ferramentas, a sua inserção na sociedade, indagações como: vive-se na Era da informação ou do conhecimento? Além de relatar a exclusão e a inclusão digital.

No terceiro capitulo, discorre-se sobre o tema de forma mais intensa, em que se fomenta acerca das TICs como ferramentas de aprendizagem do Ensino de história; em que são mencionados os nativos digitais $\mathrm{x}$ imigrantes digitais, navegar é necessário: história contextualizada; Ensino híbrido de história e metodologias ativas no ensino de história.

No quarto capitulo é relatado sobre o material e métodos utilizados, e como os dados foram averiguados.

No quinto capitulo são redigidos os resultados e discussões desencadeados pela pesquisa.

No sexto capitulo é abordada a proposta que norteou as ações do projeto e todos os eixos que lhes compõem.

No sétimo capitulo são elencadas sugestões que poderão ser direcionamentos para a extensão da pesquisa.

No oitavo capitulo são discutidas as considerações finais e a significância da pesquisa para a Educação. 


\title{
2 FUNDAMENTAÇÃO TEÓRICA
}

\subsection{Historicidade das TICs (Tecnologia de Informação e Comunicação)}

Essas ferramentas digitais denominadas TICs advêm de meados da década de 1970, mais precisamente com o auge da terceira Revolução Industrial, chamada de Revolução Informacional ou Revolução Tecnológica. (MORAES, 1993). A necessidade de dispor de recursos capazes de aliar pesquisa e eficiência nos processos de industrialização que a terceira Revolução Industrial provocou, haja vista que a mesma ocorrera logo após o fervor da segunda guerra mundial e os embates políticos, econômicos e educacionais trazidos por essa.

Reforçando essa concepção, Braga (2013, p.39) menciona:

\begin{abstract}
A revolução industrial centrada em máquinas teve um grande impacto nos modos de produção e nas relações econômicas e socioestruturais mais amplas. Houve uma alteração significativa no processo de urbanização e na natureza do mercado de trabalho.
\end{abstract}

A robótica consistiu numa das ferramentas chaves nesse processo que a indústria precisava fortalecer para suprir as demandas causadas pelos destroços oriundos da guerra. Desse modo, os primeiros passos para a inserção das TICs na sociedade apresentaram-se de modo contundente, perpassando para as outras áreas, como a Educação que será explorada no decorrer desse estudo.

O auge desses dispositivos tecnológicos ocorre na década de 1970, mediante as pretensões de absorver, propagar de modo vertiginoso e incontestável as informações, repassando-as pela televisão, rádio pela internet, até então novidades na época.

Verificando o contexto englobado maciçamente da presença desses aparatos tecnológicos que invadiram as casas, por intermédios de eletrônicos, eletrodomésticos, uma gama de produtos que facilitam a otimização de muitos afazeres domésticos. Servindo ainda como elo para estabelecer comunicação com familiares que estão distantes, como é o caso dos celulares, e dos aplicativos mais inovadores que os celulares digitais carregam, isto é, as chamadas de vídeos que faz com que vejam e interajam com pessoas há quilômetros de distância com uma precisão exitosa. Permitindo que a comunicação entre diferentes lugares aconteça 
com uma velocidade gigantesca. As tecnologias estão tão próximas e presentes, que nem se percebem mais que são tão intrínsecas à vida dos indivíduos.

Nessa perspectiva Kenski (2004, p.18) salienta:

\begin{abstract}
As tecnologias estão tão próximas e presentes, que nem percebemos mais que não são coisas naturais. Tecnologias que resultaram, por exemplo, em talheres, pratos, panelas, fogões, fornos, geladeiras, alimentos industrializados e muitos outros produtos, equipamentos e processos que foram planejados e construídos para podermos realizar a simples fundamental tarefa que garante nossa sobrevivência.
\end{abstract}

Em decorrência disso, a sociedade vigente está à mercê da industrialização e dessa globalização frenética, em que cada vez mais, as pessoas precisam conectarse a essas redes para que não se tornem indiferentes e marginalizados quanto às informações e situações que perpassam em seu meio. Hoje, a tecnologia é encarada como um dos marcos que refletem os indivíduos e seus comportamentos, haja vista que a relação promovida pela Revolução Tecnológica ultrapassou as mais diferentes conjecturas sociais.

Percorrendo a história, notou-se que a necessidade se empreendeu como mola propulsora das novas invenções, principalmente quando se fala em escrita. Mesmo com a utilização de textos e objetos para fazer registros, a locomoção destes nem sempre poderiam executar-se, devido a isso, muitas informações deixavam de ser repassadas e ficavam estagnadas. Com a criação obtida pela tecnologia do pergaminho e do papiro, onde se originou os rolos, partes consideráveis dos empecilhos solucionaram-se.(BRAGA, 2013).

Entretanto, a velocidade que a tecnologia evoluiu, o cordex, isto é, o formato de livro, onde se pode ler passando as páginas, ao qual se conhece, mostrou-se possível, devido à expansão tecnológica presenciada socialmente. Ressalta-se nessa perspectiva o quão a revolução tecnológica desbravou os diferentes contextos históricos e as invenções originadas.

Reforçando essa concepção Tardif (2014) menciona que esses dispositivos iniciaram na ordem material, através da exploração dos meios (desenho sobre madeira). Ocasiões que desempenharam ampliação da cultura escrita até as parcelas da sociedade até então excludentes do processo de aprender, chamadas iletradas e totalmente submissas as inquisições propostas pela igreja. 
Máquinas que hoje são colocadas como ferramentas de otimização de vários processos para realização de trabalhos, como é caso do computador digital, dispositivo do século XX, mas que já fora estudado séculos anteriores para efetuar cálculos, dentre outras práticas. Demonstra-se o percurso histórico dos dispositivos digitais e as funções que estes possuem largamente na vida dos indivíduos.

Cabe-se ressaltar que a tecnologia ultrapassou barreiras e conquistou uma variedade de dependentes desta, para o fomento à pesquisa e à descoberta de soluções para a profilaxia de muitas doenças e tratamentos intensivos que só foram possíveis, mediante aos engendramentos que esta desencadeia. É essa visão de progresso e evolução incalculável que corrobora o mecanismo chamado tecnologia e todas as vertentes que a mesma envolve.

Em cima disso, Kalinke (1999, p.15) salienta:

Os avanços tecnológicos estão sendo utilizados praticamente por todos os ramos do conhecimento. As descobertas são extremamente rápidas e estão a nossa disposição com uma velocidade nunca antes imaginada. A internet, os canais de televisão à cabo e aberta, os recursos de multimídia estão presentes e disponíveis na sociedade. Em contrapartida, a realidade mundial faz com que nossos alunos estejam cada vez mais informados, atualizados, e participantes deste mundo globalizado.

Mostra-se que a acessibilidade dos indivíduos, a teia de aparatos tecnológicos e a criação de várias categorias digitais têm facilitado uma comunicação irrestrita somente a fala, mas a exposição de símbolos. Ao passo que as pessoas possuem maiores caminhos e possibilidades para permearem neste mundo tecnológico e todas as potencialidades que o mesmo estabelece.

Anos anteriores a esse exercício de acesso à internet, as redes sociais, sites, dentre outras ferramentas restringia-se ainda a lan houses (casas, locais para utilizar a internet). Até as classes de menor poder aquisitivo transladava por esses ambientes virtuais, até mesmo, por conta dos valores, que eram acessíveis para a maioria das classes sociais. Serviam como verdadeiros pontos de encontros, mapas afetivos para interação entre os indivíduos.

Não obstante essas redes de comunicação, esses espaços estão cada vez mais escassos de internautas, devido à internet nas residências, nos dispositivos móveis, através dos pacotes de internet. Os celulares digitais são computadores portáteis, dependendo do aparelho e de sua evolução, é capaz de desempenhar funções mais efetivas do que os próprios computadores de mesa. Então nota-se que 
adentrar no mundo da tecnologia de informação e comunicação soa como forma de acompanhar o progresso da Revolução Tecnológica desenfreada.

Por isso, a aquisição de saberes técnicos, científicos e mutuamente aprofundados para a obtenção de aplicabilidade desses conhecimentos, resultaram nas mais distintas e inimagináveis maravilhas digitais que sofreram modificações e passam por reciclagens constantes no decorrer das eras que estão inseridas.

Analisando essa vertente de modificações exorbitantes, Castells (2011, p.69) menciona:

A principal característica da revolução da tecnologia da informação é a
aplicação desses conhecimentos e dessas informações para a geração de
conhecimentos e de dispositivos de processamento/comunicação da
informação, formando um ciclo de realimentação cumulativo entre a
inovação e seu uso.

Em outras palavras, a revolução tecnológica alicerça-se em um dos principais marcos que o planeta alcançou nos últimos séculos, em especial nas últimas décadas. Cada vez mais, dispositivos estão sendo gerados, técnicas sendo aprimoradas, e o uso destes aparelhos é intensificado, uma teia, onde a principal alimentação recai na facilitação da vida humana em suas mais distintas tarefas.

\subsubsection{Conceituação}

Denominada por diversos estudiosos de sociedade da revolução tecnológica, já por outros de sociedade da difusão do conhecimento e da aprendizagem, mas sendo percebida de modo mais acentuado como a sociedade da informação ágil. Observa-se com essa denominação que, novos perfis de cidadãos estão sendo formados. Pessoas que sejam conscientes de todas essas mudanças vertiginosas que o mundo está enfrentando. Mediante a isso, esses aparatos tecnológicos que abrangem e condicionam esse processo são chamados de Tecnologias da Informação e Comunicação (TICS).

Conforme Vieira (2003), as tecnologias são os intermédios de auxilio, os dispositivos que os professores empregam em suas aulas para incrementar e explorar conhecimento dos educandos. Desde situações simples que os professores utilizam em suas aulas são consideradas como tecnologia, até a forma de organização das cadeiras. O pincel utilizado para escrever no quadro e estabelecer 
comunicação entre os sujeitos do processo também são colocados como tecnologia. A forma de enxergar o outro e estabelecer comunicação são aspectos que a tecnologia preconiza.

$\mathrm{Na}$ afirmativa de Silva (2003), as TICs são recursos tecnológicos capazes de subsidiar o processo educacional, tanto em sala de aula, quanto em seu entorno e nas extensões da escola que é a sociedade, dinamizando o processo de ensino e de aprendizagem dos educandos.

As mesmas apresentam-se como ferramentas mediadoras no processo de transmissão de informações subsidiados pela incorporação da tecnologia. $\mathrm{Na}$ sociedade regida de transformações e de mudanças desenfreados, torna-se imprescindível conhecer essa terminologia que abarca a vida e uma somatória de instrumentos e de situações que são viabilizadas por esse arranjo estrutural que se vivencia.

Então, em linhas mais especificas, de acordo com o Wikipédia (2009) site referência em pesquisas, as TICs são definidas como todas as tecnologias que acarretam e interligam os meios de informação e comunicação dos indivíduos. Sendo ainda entendidas como um leque de ferramentas agregadas entre si, desencadeando atividades de hardware, software e telecomunicações, a automação e comunicação dos norteamentos de negócios, da pesquisa científica e de ensino aprendizagem.

Exemplos de TICs, segundo a Wikipédia (2009):

- $\quad$ Computadores pessoais (PCs, personal computers);

- $\quad$ Câmeras de vídeo e foto para computador ou Webcams;

- $\quad$ Gravação doméstica de CDs e DVDs;

- Suportes para guardar e portar dados como discos rígidos ou hds, cartões de memória, pendrives, zipdrives, entre outros;

- Telemóveis ou celulares;

- TV por Assinatura, TV a cabo, TV por antena parabólica, TV por parabólica, TV digital;

- $\quad$ Correio eletrônico (e-mail) e as Listas de discussão (mailing lists);

- Internet, a World Wide Web, websites e home pages, quadros de discussão (mensage boards);

- $\quad$ Streaming, podcasting, wikipedia entre outros;

- Tecnologias digitais de captação e tratamento de imagens e sons (Vimeo, Ypoutube, last Fm);

- $\quad$ Captura eletrônica ou digitalização de imagens por meio de scaners;

- A fotografia, cinema, vídeo e som digital (TV e rádio digital);

- Tecnologias de acesso remoto: Wi-Fi, Bluetooth, RFID. 
Realça-se assim que, são considerados instrumentos capazes de mediar o processo de comunicação e informação entre as pessoas, de maneira que estas interajam e em muitos momentos até refutem barreiras de isolamentos, até então provocadas pelo distanciamento de regiões, países e até de cidades, em que os seres não podiam dialogar com seus pares, por falta de artefatos capazes de promover essas ações.

Dentro dessa conjectura o afloramento da utilização das tecnologias nos mais diferenciados segmentos de tarefas, apresenta-se como aceleradas transformações no âmbito da cultura, da sociedade, economia, da educação, noções estas que, transmudam para a sala de aula, diante das frenéticas descobertas da ciência, tornando assim os educadores como eixos norteadores para conviver com tais mudanças. (TORNAGHI E ALBERTO, 2010).

As TICs centram-se em arranjos indispensáveis para o novo olhar que as pessoas direcionam para a informação e a comunicação. Conceituam-se como sendo a abrangência de aparelhos eletrônicos e tecnológicos, como computadores, celulares, dentre outros acessórios tecnológicos de natureza informacional, como é caso dos softwares e outras atividades nessa mesma vertente.

Por outro lado, Lévy (2010) diz que elas vão muito além dos instrumentos físicos de ordem eletrônica, também denominadas como hipermeios e hipermídias, haja visto que, a oralidade, o papel, o lápis e todas as formas de tecnologia responsáveis por angariar a comunicação entre as pessoas, situam-se em tal denominação.

Ratifica-se assim, que as hipermídias são entendidas como os meios responsáveis pelo estabelecimento de informações entre os indivíduos, e a partir da forma como estas são organizadas, transformam-se ou não em conhecimentos. São mecanismos integradores da comunicação tão decisiva entre as pessoas.

Para que haja qualquer situação de diálogo entre os seres humanos, é necessário que a comunicação seja desempenhada da melhor maneira, mesmo que estes estejam em espaços físicos bastante longínquos, porém, com o apoio das ferramentas tecnológicas, essa conversação e entendimento entre as partes é permitido.

Por essas conceituações e definições ressaltadas é instigante aferir a relevância dessas ferramentas, dispositivos, técnicas, meios, hipermeios, hipermídias, acessórios, artefatos, dentre outras nomenclaturas que lhes são 
colocadas para a apreensão e contemplação de muitos saberes que se transportam em todas as gamas da sociedade, na qual o objetivo central é o conhecimento e as funções que Ihes conferem para a melhoria da vida social.

\subsection{As TICs na sociedade}

A tecnologia juntamente com as ferramentas digitais que esta carrega consigo, está intimamente ligada com a nova forma de percepção e comportamento das pessoas.

Dificilmente as pessoas não estão fazendo uso de alguma mídia para comunicar-se com seus pares, receber informações de jornais, dentre outras ações sociais. As TVs, os rádios, os celulares, os tabletes, os computadores, os notebooks, os laptops, ultrabooks, ipads, câmeras digitais, caixas de som, são somente alguns exemplos da infinidade de dispositivos capazes de entreter, informar, comunicar, aproximar, ligar pessoas e formar redes de conhecimentos imensuráveis. Com um clique no celular, podem-se compartilhar fotos, textos, vídeos, informações, que até então, necessitavam de mais tempo para serem viabilizadas, até mesmo meses em eras antecedentes. A informação está praticamente no alcance da maioria da população brasileira.

De acordo com pesquisas da revista (ÉPOCA NEGÓCIOS, 2018) uma das ferramentas digitais que sua ascensão é alavanca excessivamente com o passar dos anos, é o celular, mais especificamente os smarthphones e os iphones, aparelhos digitais que em sua estrutura abarcam uma gama de ferramentas e aplicativos que otimizam muitas tarefas, sendo, portanto, completos. A facilidade que os adolescentes têm para verificar mensagens, navegar na internet e utilizar os aplicativos que contém nesses aparelhos são motivos de tomadas de decisões pautadas no melhor uso destas, para aprendizagem dessas crianças, adolescentes e até mesmo pais. A preocupação dos pais é propor alternativas benéficas para seus filhos reter as informações que auxiliarão no seu desenvolvimento cognitivo e emocional. A escola assim, aparece como grande parceira nessa jornada.

A Calculadora, Word, o Excel, PowerPoint, Calendário, Google tradutor, Google sala de aula, o youtube, editor de vídeos, editor de fotos, câmeras com resoluções precisas; e redes sociais: Facebook, Instagram, Twitter, WhatsApp, Telegram, dentre outras. Compreendem as diferentes funções que este aparelho 
possui, logo, um dos objetos que os seres humanos mais verificam no seu dia a dia, chegando a fazer parte de um dos acessórios principais de suas vidas.

Para Braga (2013, p.40), isso já faz parte de uma das imposições involuntárias que a sociedade faz, visto que:

\footnotetext{
Hoje sabemos que as pessoas que não tem ou não usam celulares, também sofrem pressões sociais. Como o uso desse tipo de aparelho foi popularizado, a comunicação via telefonia móvel passou a ser explorada com uma facilidade que agiliza a definição de programas conjuntos, rearranjo de encontros ou resolução de problemas em geral.
}

Percebe-se assim, que constantemente as pessoas estão penetrando neste mundo digital, haja visto que, ou se adequam às mudanças sociais, ou então se tornam invisíveis e exclusos dos acontecimentos, pois a tecnologia ganhou força grandiosa nas mais diferentes tarefas da vida humana.

A fim de compreender o ingresso da tecnologia em algumas camadas da sociedade e a maneira como suas ferramentas se popularizaram rapidamente, como é caso da internet, a mesma trouxe consigo promessas gloriosas. Dentre elas, maiores expectativas de se imergir ao mundo das pesquisas e ter participação política mais eficaz, posto que, as ideologias seriam compartilhadas por um número maior de pessoas. (PISCHETOLA, 2016).

Verifica-se assim, a nova cultura mundial como fornecedora das infinitas maneiras de vislumbrar a tecnologia e suas mídias para o exercício de tarefas até então, inimagináveis num curto período de tempo. Por exemplo, há décadas, o celular era um aparelho limitado à classe média, visto que seus valores eram altos e suas funções não eram tão exitosas, como são hoje. Os celulares, principalmente os smartphones são constituídos de várias funções que favorecem ao indivíduo delegar instruções e organizar empresas, seus negócios e até mesmo trabalhar somente digitando em seu aparelho. Salienta- se ainda, que os valores destes aparelhos estão mais acessíveis à aquisição das classes menos favorecidas.

O profissional Youtuber, isto é, pessoas que produzem vídeos dos mais diferentes assuntos no aplicativo Youtube, uma espécie de canal de compartilhamento de vídeos com várias temáticas, como: culinária, futebol, humor, músicas, entretenimentos, notícias, aulas, além de outros enfoques, compartilham essas produções na rede e recebem capitais, de acordo com as visualizações e curtidas que essas postagens geram. Enfatizando assim, que as mídias digitais 
estão próximas do contexto que engloba as mais diferentes funções e a maneira como esta é desenvolvida concebe benefícios para os seus agentes.

As videoaulas, isto é, aulas que são fabricadas em sua grande maioria por professores ou profissionais de áreas especificas, com conteúdo de modo claro, metodologia diferenciada, pautando-se em dinamizar o saber, para que este seja assimilado pela maioria dos usuários, alunos, pessoas que verão e acessarão esses vídeos. Por isso, "o profissional competente deve não apenas saber manipular as ferramentas tecnológicas, mas incluir em suas reflexões e ações didáticas a consciência de seu papel em uma sociedade tecnológica". (BRITO E PURIFICAÇÃO, 2008, p.5).

Cabe assim, a esses profissionais não somente a transmissão otimizada e eloquente de aulas simplificadas, mas agregar em seus vídeos a preponderância de criticidade nos assuntos que serão pesquisados na Web.

Neste cenário Pischetola (2016, p.52) corrobora:

\begin{abstract}
A tecnologia digital oferece novas oportunidades de aprendizagem, visto que a interação com os dispositivos digitais é uma ação livre capaz de estimular a curiosidade. Essa interação oferece ao usuário a possibilidade de escolher as vias de acesso a informação que lhe interessem, selecionar a informação que prefira, acessar os mesmos conteúdos quantas vezes quiser, buscando novas e mais significativas aprendizagens, e ainda produzir e socializar novas informações.
\end{abstract}

Segundo essa estudiosa, fica evidente que a acessibilidade a essas ferramentas digitais e a quantidade ampla de recursos que as mesmas oferecem são incontestáveis. Contudo, requer mais análise e critérios para que as informações consigam transformar-se em aprendizagens efetivas e de qualidade, uma vez que, existem várias fontes, mas necessita-se compreender e apontar a mais ou as mais fidedignas.

\title{
2.3 Era da informação ou a era do conhecimento?
}

Denominada por muitos pensadores como a sociedade da tecnologia, sociedade do conhecimento ou da aprendizagem. (TORNAGHI, 2010). Essa conjuntura social em que os conteúdos são rapidamente difundidos, provocando novas formas de agir e refletir. 
No bojo do encadeamento de transformações nos mais diferentes setores da sociedade e a quantidade de informações que são disponibilizadas, reforça-se a necessidade de formar indivíduos capazes de identificar e selecionar as informações pertinentes aos seus anseios, resultando em saberes significativos, ao passo que estes serão averiguados, dando-Ihes munições para que aprendam incessantemente no decurso de sua existência.

Vive-se numa esfera repleta de dados, nortes, estruturas, mas que não são suficientes para evidenciar se o conhecimento encontra-se instaurado. De acordo com Luckesi (2010) o conhecimento é a capacidade de interpretar a realidade e a maneira como os indivíduos organizam as investigações para descortinar o novo e avançar, almejando em todo percurso a melhoria do seu contexto.

Nesse sentido, a informação modifica-se continuamente, tornando 0 conhecimento ponto de partida, para que tais dados, não beirem a obsolescência. A capacidade de permear-se num universo considerável de informações, onde o acesso aos assuntos e conteúdo são instantâneos, sem muitos critérios, não demonstra se a sociedade alicerça-se de muitos saberes e transforme seu entorno. O processamento dos dados e a função social que estes empregam são incitações essenciais para chegar a tão sonhada sociedade da aprendizagem ou do conhecimento.

Em consonância a essas reflexões, Pischetola (2016) reporta-se a informação como um apoio indispensável para o tecimento de decisões, pois é, a partir da mesma que o sujeito constrói ligação protagonista com o mundo, no que tange as relações de cunho político, social e intelectual. Entretanto, a sua eficiência não é totalmente realizada, haja visto, que a sociedade ainda se alarga em diferenças e disparidades de oportunidades em relação a tais fontes.

Frisando assim, para que essa informação seja sustentada de papel significativo de oportunidades, acarretando condições favoráveis para o coletivo, fazse necessário entender, absorver, processar e transformar essas informações, ascendendo-as a aprendizagem.

Nessa concepção, Salgado (2009, p.9) instiga "a informatização do conhecimento tornou muito mais acessíveis todos os saberes ao tornar mais horizontal e menos seletivos a produção e o acesso ao conhecimento." Com isso, atingindo a prática de que a sociedade em ênfase se atrela na informação 
exacerbada, precisando preconizar mecanismos para que tais informações despertem e beneficiem a melhoria social.

Faz-se necessário que a formação de cidadãos críticos e discernidos intelectualmente, potencializada por Mórin (2001), na medida em que esta seja democrática em seu cognitivo, formando-os em prol de estimularem as suas potencialidades, através de estratégias no que diz respeito as informações que lhes são disseminadas, objetivando que esta informação às vezes desordenada, angarie o conhecimento eficaz.

Nessa observância, Pozo (2003) experencia-se a sociedade de informação, a qual só se assimila a uma efetiva sociedade do conhecimento para uma minoria de pessoas, aquelas que de alguma maneira utilizaram a rigor as capacidades de ordenamento das informações para que estas alcançassem o seu patamar mais ansiado, o conhecimento.

Dessa maneira, o incremento de várias facetas para um determinado assunto acarretou mudanças culturais incomensuráveis, ao passo que muitas inquietações surgiram entre os indivíduos, tendo em vista, que as informações estão em constantes mutações. Os pontos de vistas englobam as incertezas, as verdades absolutas rechaçam-se com as novas descobertas, o relativismo dos fatos alcança seu ápice.

Em concordância com Mórin (2001) o mais importante é aprender a conviver com as diferenças de visões, com o relativismo das suposições, com as variadas perspectivas de entendimento de um assunto, para que as informações auxiliem na construção de seus princípios e prismas de opiniões.

Nessa vertente, Salgado (2009, p.31) profere:

não cabe mais a educação proporcionar aos alunos conhecimentos como se fossem verdades absolutas; ao contrário. Ela deve ajudá-los a construir o seu próprio ponto de vista, sua verdade particular a partir de tantas verdades parciais."

Sabendo-se que a teoria escolar vigente ainda orienta-se por tradições jesuíticas nas quais a repetição e a memorização tecidas pelos professores são preponderantes em todo o processo de ensino aprendizagem.

Em divergência com essa prática, o ritmo acelerado das mudanças tecnológicas que se presenciam, os conhecimentos que os indivíduos precisam 
dominar não conseguirão ser previstos, mas o sistema de ensino carrega consigo a responsabilidade de formar pessoas flexíveis às mudanças, eficazes e onde a autonomia tenha grande participação em suas decisões, pois as aprendizagens estão em constante sintonia com as mídias digitais.

Com a ascensão desse paradigma estabelecido de Era da Informação ou Era do Conhecimento, Salgado (2009) destaca que essa sociedade da aprendizagem carece adquirir cinco tipos de capacidades que estão atreladas a Gestão do Conhecimento ou Gestão Metacognitiva, tornando-os envolvidos e aptos a responder as adversidades propostas, nos mais distintos segmentos da vida pessoal, afetiva e social.

Com isso, Pozo e Postigo, (2000, p.87) elencam-nas:

- $\quad$ Competências para aquisição de informação

- Competências para interpretação da informação

- $\quad$ Competências para a análise da informação

- Competências para a compreensão da informação

- Competências para a comunicação da informação

Ainda assim, é irrefutável perceber que a nova demanda social de indivíduos, dos quais convivem com uma amplitude de informações, que nem sempre condiz com os processamentos necessários à absorção de conhecimentos e modificações de seus meios, solicita novos delineamentos de educadores e educandos. Mesmo assim, essa acessibilidade para Era do conhecimento só será reconhecida nas suas facetas totalitárias, quando a renovação da mentalidade dos indivíduos se cumpra e permeie-se nesse meio digital como seu apogeu.

\subsubsection{Exclusão digital}

O insucesso em muitos ramos da sociedade, mas principalmente os de alcunha educacional perpassam pela exclusão e marginalização que as classes menos favorecidas enfrentam diariamente, seja em condições de acesso, no tocante a igualdade ou equidade de oportunidades no cenário escolar.

Quando se trata da história do conceito exclusão digital, as características assemelham-se e nutrem-se de óticas complexas, nesse enfoque Pischetola (2016, p. 21) decorre: 
[...] está relacionada com as disparidades econômicas e sociais, em escala global, que existem entre os países industrializados e os países em desenvolvimento. Geralmente, o conceito se refere as desigualdades no acesso e uso das tecnologias digitais, mas a aparente simplicidade dessa definição esconde questões conceituais difíceis de resolver, inclusive de explicar.

É perceptível que as mídias digitais e o a acesso a esses hipermeios na explicação da autora advém de questões econômicas, mas como o enfoque da pesquisa é de abrangência educacional, analisam-se os fatores e a conceituação dos referidos termos pela literatura.

Observam-se assim, que os primeiros indícios de exclusão digital ocorreram com a identificação de problemas na agência de telecomunicações (NTIA), nos Estados Unidos, análises essas que, relataram as discrepâncias no próprio país no que tange $o$ acesso as telecomunicações.

Num segundo momento, essa exclusão é captada de acordo com as desigualdades socioeconômicas das pessoas, com relação à acessibilidade, as tecnologias da informação e comunicação que são objetos da pesquisa em curso.

A partir desses relatórios criaram-se as nomenclaturas: "ricos em tecnologia" e os "pobres em tecnologia". Fomentando assim, a centralização heterogênea do que tem acesso as TICs e os que não possuem. (Pischetola, 2016).

O não acesso encontrado por muitos indivíduos no que tange a utilização das TICs alertam para uma discussão polêmica: não se utiliza as hipermídias pelo fato de não saberem manusearem tais aplicativos? Os valores desses produtos são abusivos? As pessoas têm receio em não conseguir dominar tais equipamentos?

Portanto, tais questionamentos são refletidos com frequência em vários debates que permeiam o cenário educacional, quando estes focalizam a tecnologia, haja visto que a escola é a ruminação da sociedade em todos os seus desdobramentos. Portanto, o acesso as TICs torna-se cada vez mais possível, se essas questões forem debatidas por um contingente maciço de indivíduos, mostrando que as mesmas utilizadas com a criticidade necessária ajudarão muitas pessoas, em especial crianças na construção de seus saberes, levando tais conhecimentos aos seus membros familiares.

Mediante a essa ótica de exclusão digital, a Educação corrobora-se como ponto de desmembramento para que o acesso a tecnologias e suas mídias evolvam 
um número maior de indivíduos, tornando-os empreendedores de seus pensamentos e autores de suas histórias.

\subsubsection{Inclusão digital}

O acesso à tecnologia e suas amplitudes na promoção de informações capazes de estabelecer conexões entre os indivíduos estão em evidencia. Nesse enfoque Rodriguez (2011, p.25) decorre:

[...] os esforços para o desenvolvimento de estratégias especialmente voltadas para a apropriação das TIC por comunidades digitalmente excluídas, passa pela capacitação de seus integrantes para o uso efetivo de tais recursos. Essa capacitação é parte fundamental, capaz de possibilitar a inserção crítica e consciente dos mesmos no dia-a-dia dessas comunidades.

Posto isso, essa inclusão é marcada por uma gama de fatores, haja visto que, desde a formação dos profissionais que vão subsidiar o processo de manuseio dos equipamentos, até a aquisição desses aparelhos, incitando nestes a busca duradoura que deve existir para que a realização dessa tarefa de inclusão às novas tecnologias não seja rechaçadas com os primeiros empecilhos que surgirem.

Pautando-se que a democratização de tecnologia e seus recursos vêm sendo bastante explorados nos discursos fervorosos que aludem a Educação. No entanto, a prática de políticas e ações que priorizam e estimulam esse acesso ainda estão muito aquém das falácias. A teoria insiste em sobressair-se diante da prática. Por isso, atividades na escola que fomentem e provoquem na comunidade escolar 0 convívio e o exercício da tecnologia em suas tarefas diárias, atenuarão de modo contundente, beneficiando os indivíduos nesses aspectos.

Para Móran (2015) as escolas são espaços agregadores para que os alunos se distanciem dos ambientes quadrados para redesenharem suas expectativas em locais abertos à interação provocada pela tecnologia.

Verifica-se assim, a incorporação ainda de modo tímido, como por exemplo, em ínfimas escolas periféricas, em que o acesso à internet é limitado, chegando muitas vezes a nem existir em decorrência do desprovimento de recursos nessa ótica, comprometendo a investigação de fontes sobre os assuntos que são 
abordados para os alunos. Momentos de interação com o contexto social vigente através de viabilizações que a tecnologia promove.

\section{AS TICS COMO FERRAMENTAS DE APRENDIZAGEM NAS AULAS DE HISTÓRIA}

A incorporação das TICs no ambiente escolar amplia o aspecto cognitivo, aflorando o lado crítico e a aprendizagem coletiva, visto que permite a interação entre os educandos, para que as diferentes mídias sejam exploradas. Mostrando assim que as aulas podem dotar-se de protagonismo e principalmente de sujeitos ativos no processo de apreensão de saberes que lhes são postos.

Segundo Móran (2015, p.31):

Aprendemos mais e melhor quando encontramos significados para aquilo que percebemos, somos e desejamos, quando há alguma lógica nesse caminhar- no meio de inúmeras contradições e incertezas-, a qual ilumina nosso passado e presente, bem como orienta nosso futuro.

Dessa maneira, não podemos deixar de enfatizar uma das grandes disciplinas que compõem o currículo escolar das escolas, isto é, a disciplina de história, ramo do saber que desenvolve no aluno uma somatória de vertentes imprescindíveis para o entendimento da sociedade em que estamos inseridos.

Ainda nessa vertente, Móran (2015, p.33) relata:

A aprendizagem é mais significativa quando motivamos os alunos em seu íntimo, quando eles acham sentido nas atividades propostas, quando consultamos suas motivações profundas, quando engajam em projetos criativos e socialmente relevantes.

Logo a transmissão, ou melhor dizendo, as inquietações e reflexões que o ensino de história propicia necessitam pautar-se de mecanismos facilitadores do dinamismo em sala de aula, como as TICs e as ferramentas pedagógicas que estas nutrem.

Enfatiza-se assim, que as aulas de história consistem em meios onde o conhecimento do aluno é colocado em conflitos com contextos históricos que nortearam gerações e que são fundamentais para entendimento do presente, passado e conexões com o futuro. 
Em relação a isso, Hoffing (2003, p. 02) propõe:

O ensino de história mudou muito nos últimos anos e os alunos são considerados participantes ativos na construção do conhecimento. Deve-se estabelecer relações, construir noções de diferenças e semelhanças, continuidade e permanência. Compara acontecimentos no tempo, como referência os conceitos de simultaneidade e tempo/espaço.

É incontestável reconhecer que os instrumentos tecnológicos não são o centro principal no encadeamento de ensino aprendizagem, porém apetrechos capazes de viabilizar a relação mediadora entre professores e alunos, conhecimentos científicos com empíricos, onde o tão criticado modelo pedagógico bancário denominado por (Freire, 1993) seja superado por metodologias que incorporem a tecnologia de modo articulada com o direcionamento de saberes efetivos e transformadores na vida do aluno. Onde os saberes aprendidos na escola façam sentido nas suas vidas e nas suas ações.

Segundo Aoki (2004, p. 45),

[...] as Tecnologias de Informação e Comunicação - TICs, como recurso em situações de ensino-aprendizagem proporcionam ao professor uma mudança de papel, pois este deixa de atuar como "conhecedor", "repassador" e "transmissor" do conhecimento, para ser "orientador", o "facilitador" e "promovedor" da construção do conhecimento.

Por isso, as aulas de história alicerçadas pelos aparatos tecnológicos evidenciam essa ruptura com a estagnação que as aulas monótonas causam na trajetória dos alunos, ao passo que estes são aguçados a explorar e trabalhar com esses equipamentos seja por meio de um vídeo, ou até mesmo de uma pesquisa complementar no aparelho celular dos seus próprios pais. As dimensões de desenvolvimento integral para o entendimento de civilizações, até então vistas somente nos livros e na memorização que suas aulas Ihes propõem.

\subsection{Nativos digitais $\mathrm{x}$ imigrantes digitais}

Essas duas terminologias estão sendo bastante debatidas nos discursos educacionais, ao passo que com o passar dos anos, o surgimento de apetrechos digitais que as crianças podem desfrutar tanto no seio familiar, quanto no seio 
educacional, disseminou esse desmembramento de indivíduos, isto é, os que nasceram na era digital com incontáveis recursos tecnológicos.

Por outro lado, aquela geração que necessitou adaptar-se a essa nova engrenagem da sociedade, em que os fatos são proliferados numa fração de segundos. Geração essa acostumada a tecer suas vivências com visitas para seus amigos, brincar de bonecas, carrinhos, em detrimento de passarem horas com um celular na mão, onde o mundo é compartilhado de forma veemente. São esses dois perfis de indivíduos que a escola dispõe, de forma mais acentuada, a geração da tecnologia.

A primeira conceituação são os chamados nativos digitais, utilizando o sentido literal da palavra, assim, como os indígenas que já estavam em terras brasileiras com a chegada dos portugueses, assim, também são os nativos digitais, já nascem com a tecnologia a todo vapor e criando ferramentas que fazem papéis inimagináveis e auxiliam consideravelmente na construção de saberes críticos e refutáveis, haja vista que as fontes alargam-se. Não obstante, ainda são verificados uma parcela considerável da população em que a tecnologia e suas ferramentas ainda não chegaram em suas casas, e se chegaram os mesmos encontram-se dispersos a essas inovações, seja por escolaridade, ou até mesmo rejeição. A condição financeira também aparece com grande fator para que os aparelhos tecnológicos não figurem na casa e nas mãos de muitos cidadãos. Posto que, infelizmente as desigualdades permeiam a sociedade de modo desenfreada.

Ainda nessa perspectiva, Braga (2013, p.64) destaca:

\begin{abstract}
A literatura atual tem feito uma distinção entre os chamados " nativos digitais", a população mais jovem que já cresceu familiarizada com as TICs, e os chamados "imigrantes digitais", que dominam a cultura letrada tradicional, mas que precisam ou optam pelo uso das práticas letradas realizadas nos meios digitais.
\end{abstract}

Em consonância a essas terminologias é interessante averiguar como os imigrantes digitais alunos e professores e os nativos digitais alunos e professores estão agindo nessa perspectiva, em destaque na disciplina de história, uma vez que, por tratar-se de uma disciplina tão pouco explorada pelos professores, no que tange a recursos, pois o livro já é notado como base para que tais conteúdos sejam transmitidos. 
Convergindo com a significância dos nativos digitais, é interessante destacar a concepção de Móran (2015, p.41), acerca de tais fatores que alicerçam essa concepção:

\footnotetext{
É importante que os projetos estejam ligados a vida dos alunos, as suas motivações profundas, bem como que o professor saiba gerenciar essas atividades, envolvendo os estudantes, negociando com eles as melhores formas de realizar a tarefa e valorizando cada etapa, principalmente a apresentação e a publicação em um lugar do ambiente virtual que seja visível para além do grupo de classe.
}

A partir disso, os alunos nativos digitais e esse professor que encontra-se em formação são colocados como inovadores e multifacetados de informações e de noções que se tratadas e averiguadas com a criticidade necessária resultarão em conhecimentos significativos para suas vidas. Dependem exclusivamente estarem em todo trajeto buscando novos cenários de aprender e de construir com o outro, na medida em que a tecnologia torne-se aliada nesse processo, tanto de recursos para os professores nas aulas de história, buscar métodos eficazes de inserir os alunos nas mais diversas épocas, através de filmes, jogos eletrônicos, videoaulas de animação, construção de slides entre os alunos, pesquisas dos assuntos estudados. Deixando esse aluno e professor numa mesma plataforma de geração de conhecimentos, onde suas dúvidas sejam tratadas como inquietações indispensáveis para que as próximas aulas sobre a história de qualquer civilização os deixem curiosos e estimulados a envolverem-se, e trilharem pelo mundo dos desbravamentos do novo e o respeito ao velho.

Com esse olhar de humanismo que os nativos digitais desenvolvem o senso crítico e móvel que a história busca ao logo de suas primeiras formas de resgatar os contextos da humanidade. O ensino de história, em que os alunos constroem junto com seus docentes, as linhas de conhecimentos auxiliados pela tecnologia e suas bases estruturais dinâmicas, onde os conteúdo não se resguardem apenas na leitura e transcrição de perguntas, e o aluno é um ser passivo, um mero depósito de informações indubitáveis, não é esse cenário que os nativos mergulham.

Salientando as características dos nativos digitais, Lemos (2009) reforça que os mesmos são priorizados pela conexão através de gráficos e imagens, ao invés de leituras imóveis. Buscam a dinâmica. Por isso, o livro didático e a leitura deste não são aguçadores no processo de lecionamento das aulas de história, uma vez que os 
alunos sentem-se off-line, ou seja, desligados nesse encaminhamento do saber, ao passo que a ferramenta da transcrição de datas, nomes de heróis e vilões de variadas épocas surgem como mais essenciais do que a própria narração que os alunos fazem, quando já desvendaram diversas fontes e as entrelinhas de uma mesma temática, desencadeados pelo uso dos apetrechos e conjecturas tecnológicas.

Não obstante, os imigrantes digitais nasceram num contexto onde a tecnologia não tinha essa desenvoltura eloquente e veloz. Sua forma de absorção dos saberes pautava-se na leitura e releitura de livros, sem dispor de aparatos digitais em que os conhecimentos são compartilhados em tempo real e com precisões respaldadas.

Palfrey e Gasser (2011) relatam que a familiaridade dos imigrantes digitais com o meio digital é pequena, logo necessitam aprender no transcurso da vida a utilizar ferramentas para sua comunicação social, como por exemplo: criar e-mails e redes sociais.

Sabendo-se que os imigrantes são oriundos de outro contexto, por sua vez, totalmente alheios às tecnologias digitais, o tradicionalismo nas aulas de história vivenciou-se o dogmatismo dos professores imigrantes com saberes e didáticas inertes. Contrapondo-se a esse novo tipo de aluno nativo, onde a tecnologia digital está presente nas mais simplórias ações que esta executa em sua vida. Mostrando assim, essa divergência de ideias que esses dois indivíduos apresentam.

Sendo assim, não tem como falar dos professores imigrantes digitais sem fazer ponderações essenciais na sua formação, para que o convívio com os alunos nativos digitais não pereça no marasmo que os conteúdos de história transmitidos sem mecanismos tecnológicos eficazes, acarretando na aprendizagem despretensiosa e sem alcunha de significância.

\subsection{Navegar é necessário: ensino de história contextualizado}

$\mathrm{O}$ arranjo social vigente faz com que as mudanças no sistema de ensino tornem-se urgentes, em especial para aquelas disciplinas tidas como "decorebas", onde o aluno precisa limitar-se a reproduzir datas e contextos históricos, pela ótica dos materiais impressos e pela fala do professor. Deixando assim, essa disciplina primordial para análise e entendimento da sociedade chamada história, repleta de 
descontentamento e falta de interesse dos alunos. Onde a mesma é capaz de significar e ressignificar papéis de personagens que foram essenciais para a construção do mundo nas suas mais variadas instâncias, por isso o docente que navega pelas características exigências de sua época transforma-se não apenas em um transmissor de ideias, ideologias, mas um debatedor de opiniões e formador de indivíduos capazes de situar-se com reflexões pontuais, essencialmente quando essas ações se iniciam na base.

Esses recursos que o ser humano possui onde a sua função é desempenhar ações de modo mais práticas, como por exemplo, o clique de um celular permite ao docente disponibilizar PDFs, vídeos, sites, blogs, dentre outros recursos regidos de uma gama de conteúdos que servirão como complementos para os assuntos que estão sendo desenvolvidos em sala de aula.

Nessa conjectura, esses apetrechos estão intrinsecamente ligados a vida das pessoas, logo a escola, necessita alinhar-se a esse mundo digital que abriu espaço para que o diálogo entre os educandos e docentes se torna mais amplo e horizontal. Os conteúdos de história, por exemplo, os povos pré-colombianos: Astecas, Maias e Incas podem ser percebidas em jogos, ao passo que as características dessas civilizações são apresentadas nas fases que contemplam esse aplicativo de divertimento educação.

Esse despertar para a contextualização que os elementos da história constituem é um dos grandes feitos que a tecnologia proporcione, para que esse processo de ensino aprendizagem seja flexível e interligado com a realidade dos sujeitos que os constrói.

Ao deparar-se com esse sustentáculo vertiginoso de informações e de confrontos de pensamentos oriundos das mais diferentes fontes, torna-se crucial que as aulas contemplem esse perfil de mentalidade que estão sendo geradas.

Logo, a disciplina de história e os inúmeros caminhos que esta agrega, compõe saberes inesgotáveis para que seus saberes sejam explorados com o auxílio das TICs e todos os mecanismos que esta oferece.

As aulas de história e seus enfoques não se atrelam a neutralidade, uma vez que, ou são interessantes, na medida em que os alunos viajam nos mais diferentes modelos e características de sociedade, ou são extremamente maçantes, tornando os alunos meros repositores de informações que não Ihes causarão rebuliços no seu 
intelecto, tampouco comprometidas com o verdadeiro ensejo do saber de história. (LOPES E MONTEIRO, 2016).

Em decorrência dessa nova conjuntura estabelecida pela sociedade em que estão sendo gerados, o uso de recursos tecnológicos aparece como estratégias plausíveis para despertar o prazer dos alunos em relação à produção de conhecimentos, em destaque para aquelas aulas que ainda são bastante arraigadas apenas no apoio do livro e da repetição do professor.

Os alunos nesse sentido buscam ser efetivos nesse processo, ao invés de marionetes da escola, já que seus saberes serão tecidos de forma mediadora, e com o dinamismo que as ferramentas digitais concebem.

$\mathrm{Na}$ produção dos saberes de história utilizou-se com veemência os computadores, para que as informações encontradas pudessem ser organizadas, confrontadas e compartilhadas por um número maior de pessoas, sendo eficientes para o historiador e para os professores em sala de aula, haja visto que estes teriam um repositório maior de fontes para compreensão dos fatos históricos.

Colaborando com isso:

[...] os computadores foram muito úteis às pesquisas quantitativas, como a demografia histórica. Por meio deles, tornou-se possível manipular um grande número de fontes, sistematizá-las em bancos de dados e, a partir disso, produzir gráficos, tabelas, percentuais que passaram a se constituir numa metodologia a mais para as interpretações historiográficas. (FERREIRAC E FRANCO, 2009, p. 139).

Com isso, através de uma pesquisa feita pelo computador tradicional ou até mesmo pelo computador que uma grande quantidade de pessoas tem acesso de forma exorbitante, isto é, os celulares, exímios computadores de mãos que as pessoas possuem fazem com que estas naveguem por uma amplitude de conteúdos, seja em acervos de bibliotecas virtuais, livros e demais documentos que englobam o universo das pesquisas, pois os métodos para se construir e confrontar conhecimentos amplia-se de modo impulsivo, tornando-se indispensável atualizar-se paulatinamente.

Contudo, mais do que amparar-se com equipamentos físicos a escola, como: computadores, retroprojetores, tabletes e demais engenhocas tecnológicas, a capacitação dos professores para essa pedagogia de ensino, é tão eficaz para o sucesso da educação e quando não ocorre com essas averiguações e 
planejamentos, a escola vai possuir apenas uma sala de recursos de multimídias, isto é, quando são agraciadas pelo sistema, onde são trancadas a sete chaves, e os alunos e os professores vão continuar dialogando com os saberes históricos de forma tediosa e sem estímulos para construir e reconstruir entendimentos. (GOMES, 2002).

Resultado dessa nova pedagogia de ensino aprendizagem que a disciplina de história pretende vislumbrar, as aulas contextualizadas com a realidade dos alunos e dos saberes prévios alinhadas com as potencialidades da tecnologia são de valioso benefício para que os educandos reconheçam a relevância que a história possui para a melhoria da sociedade, de modo que os alunos se tornem cidadãos compromissados e valorizadores dos resquícios e aspectos que compõem suas trajetórias.

A contextualização das pesquisas que acarretam a formação do pensamento crítico dos alunos com relação às entrelinhas da história, que de modo geral não são ressaltados no ensino fundamental, uma vez que os professores estão preocupados em repassar informações prontas, sem que estas passem pelo funil dos debates e das ressignificações. Com a mediação da tecnologia, os professores e alunos estarão ligados por fios conectados pela mesma sinergia, isto é, de profundos pesquisadores, pois a educação, essencialmente a história, tão decisiva, para que os alunos consigam o letramento necessário nas demais disciplinas, como é o caso da Língua portuguesa e da Matemática, onde as mesmas são norteadas por personagens principais, contextos e aspectos que lhes ajudam a construir seus saberes. Em cima dessas perspectivas, navegar com demasiados mananciais historiográficos são estratégias assertivas para os rumos que a Educação e o ensino de história procuram debutar.

\subsection{1 É possível o ensino hibrido de história?}

Partindo da premissa de MORAN (2015), a educação blended - ou educação híbrida - possui como intenção pedagógica deixar os alunos em sintonia com os desafios, dentre elas, o caminho para solucionar adversidades e construção de projetos substanciais, de forma grupal e individualizada. Para tanto, a orientação de docentes nesse processo de aprender pela explanação digital e física é inegável. 
Em função dessa assertiva o autor reforça que o docente averiguará as dificuldades de cada aluno. Sabendo que a Educação híbrida utiliza procedimento maleável, promovendo oportunidades de customizar e refletir sobre o que o que é relevante para abarcar as singularidades e especificidades dos educandos, incorporando, assim, meios de transmissão e retenção de saberes mais amplos, acarretando assim nas interdisciplinaridades de distintos profissionais e suas áreas para desenvolver a fusão de conhecimentos.

A sociedade constituída por essas demandas de adequação do ensino a práticas que consigam alcançar suas necessidades de aproximação mais reais com os assuntos que lhes estão sendo transmitidos, é possível averiguar que a hibridização do ensino, em reverencia ao ensino de história pode ocorrer, caso essa sinergia do professor e dos alunos preponderem.

Esses fatores são estritamente estabelecidos, uma vez que essa alternância entre o ensino online e o ensino off-line conectam-se. $O$ ensino online é caracterizado por aquele tipo de estudo, onde o aluno vai pesquisar e se aprofundar com as temáticas de história, de modo individual. Estudando em casa, no laboratório de informática, caso tenha. Suas pesquisas são realizadas com as ferramentas digitais que possuem, seja o celular e a exploração de seus APPs, o tablet, o computador e demais aparelhos que conduzam esse processo de navegar pela internet e pelas áreas da informática, buscando aperfeiçoar e estender os conteúdos que lhes foram ministrados. (TREVISAVI E FERNANDO,2015).

Possui-se ainda, o momento off-line, onde os alunos de forma grupal tecem suas dúvidas entre os próprios alunos e com professor. A interação e a coletividade são verificadas como bases nessa caminhada. Contudo, o momento online, possui pontos convergentes com fomentação de erros e acertos e da valorização de conhecer e utilizar as ferramentas digitais em prol dos aprofundamentos dos temas, uma vez que estas auxiliam no depósito de informações que Ihes geraram dúvidas e curiosidades.

No que se refere ao ensino online o indispensável é que os alunos conduzam seu tempo de estudo respeitando suas autonomias e suas responsabilidades de adentrar pelo universo da pesquisa, focalizando os objetivos da disciplina e ampliando as informações em relação às temáticas discutidas. 
O envolvimento dos educandos com a tecnologia nessa situação de ensino e aprendizagem se faz de modo dinâmico, deixando o aluno sempre na condição de produtor e transformador de conhecimentos.

Segundo Trevisani (2015), a perspectiva off-line concerne aos professores e alunos e alunos e alunos o feedback entre os conteúdos propostos em sala de aula, é como se o os alunos tivessem estudando a $1^{\circ}$ Guerra Mundial e estes alunos fossem organizar-se em equipes, para que os pontos convergentes e divergentes com tal fato pudesse ser explanado. Cada grupo faria suas pesquisas, criaria suas estratégias de argumentações, sendo por meio de paródias que precisariam do auxílio da letra da música escolhida. Nesse momento os sites de pesquisas, vídeos, imagens, dentre outros recursos tecnológicos encaminharia a discussão. Outro grupo produziria vídeos, necessitaria do editor de vídeos e demais ferramentas que contemplam tais edições.

Em convergência com tal analogia, a hibridização do Ensino de história é presumível, uma vez que, os contextos que a sociedade presencia estão em constantes ajustamentos com as conceituações de alunos que já não fixam seus pensamentos para a repetição e transcrição de acontecimentos que não fazem nenhum paralelo com as narrativas que Ihes rodeiam. Nas novelas também, se os alunos forem orientados com o prisma historiador de seus professores, irão desfrutar de diferentes épocas, podendo imaginar e recriar cenas em suas imaginações de como fora determinados fatos que até então só poderiam ser verificados, através da leitura do livro.

É perceptível que a TV é uma tecnologia de informação e comunicação colaboradora dos cenários e enredos que discorrem sobre a história do mundo, por isso, o professor, na condição de mediador incuta essa ferramenta nas atividades didáticas, levando-a ao gosto dos alunos, fazendo com que estes não se contentem com a reprodução dos conhecimentos de história, mas que se tornem personagens desse curso denominado aprendizagem significativa.

O ensino híbrido de história sugere esse complemento do modo online e offline, que são abordados com os alunos, desenvolvendo tanto nos alunos como nos professores essa flexibilidade e maleabilidade de ensinar e aprender história, ao passo de não se conformem apenas com os pontos de vistas que thes forem imputados. Essa nova metodologia de aprender e ensinar a história, intermediados 
pelas conexões da tecnologia, reitera o quanto os indivíduos mergulham na modernidade líquida que o grande sociólogo Bauman instigou.

Para Bacich, Tanzi e Trevisani (2015), os docentes ainda não detêm os conhecimentos eficazes, uma vez que a maioria desses, são imigrantes digitais. Sendo assim, em grande parte, desconhecedores das ferramentas digitais que fornecem diferentes formas de promoção dos saberes. Levando em consideração, que tais educadores são cientes de que os referidos aparatos subsidiam a contemplação de uma infinidade de informações, na medida que os mesmos podem aliadas dos professores, em especial, na disseminação dos conteúdos de história, muitos ainda insistem em não acompanhar a evolução da sociedade, deixando as aulas divergentes da criticidade prazerosa.

Nessa observância, o contato e manuseio dessas ferramentas são cada vez mais urgentes nas salas de aulas, haja visto que a sala de aula não pode estar em discrepância com a sociedade à sua volta. Nossa sociedade é regida de lócus tecnológicos, como por exemplo, as próprias residências dos alunos estão impregnadas dessas hipermídias: Celulares, computadores, televisões, caixas de som, rádios, dentre outros utensílios com a finalidade de entreter e de repassar informações.

$\mathrm{Na}$ medida em que a escola não abrange essa modalidade tecnológica, dinâmica e criativa, as aulas tornam-se menos atraentes e as potencialidades dos alunos pautam-se na passividade. No entanto, são indivíduos pensantes e inteirados com o meio e suas inovações que a educação anseia formar.

Os debates ora e outra, atrelam suas expectativas a essa dinâmica tecnológica, em discrepância com a oralidade, uma vez que na oralidade, o aluno restringe-se apenas em escutar as informações que o professor estabelece. Entretanto, quando esta passa a ter dinâmica, as informações tecidas serão refletidas e transformadas em conhecimentos. Aluno e professor partilharam de saberes memoráveis e fundamentais para a melhoria da sociedade, sendo que o desejo da educação é esse, formar indivíduos que saberão seus papeis e atuarão para que a harmonia de oportunidades exista de fato e não utopicamente.

Ainda nessa perspectiva de fornecer subsídios de melhoria para esse "serviço", Valente (2015, p.14) infere no prefácio do Livro Ensino Hibrido: 
O ensino híbrido é uma tentativa de implantar na educação o que foi realizado com outros serviços e processos de produção. A responsabilidade da aprendizagem agora é do estudante, que assume uma postura mais participativa, resolvendo problemas, desenvolvendo projetos e, com isso, criando oportunidades para a construção do seu conhecimento.

Observa-se com isso, que os serviços elencados pelo autor, são os serviços que até então se sucediam de forma burocrática e limitada a presença física, como é o caso dos serviços de bancos, em que os clientes só tinham seus dados registrados numa única agência. Quaisquer eventuais processos que necessitavam fazer, não podiam executar nas demais agências, como transferências, verificação de saldos, dentre outros. Contudo a informatização dos bancos possibilitou essa autonomia dos clientes e uma melhor qualidade dos serviços prestados pelos bancos.

A segunda analogia feita por Valente (2015) pondera-se na questão dos serviços de comércios, onde os clientes nos supermercados, por exemplo, escolhem seus produtos, transferem para os carrinhos, e alguns casos, até guardam suas compras nas sacolas. Visa-se nesse caso, uma prática totalmente divergente de anos anteriores, onde o cliente era servido. A responsabilidade do cliente avança-se para a modernidade e esse contexto de autonomia que o mundo rumina.

O referido autor nutre essa ruptura que a Educação ainda não conseguiu estabelecer, isto é, a abordagem de inovações em que coloquem os alunos como centro do ensino. Os professores não podem fixar-se como servidores de informações, em especial, quando as disciplinas são estereotipadas como "complementares" exemplificando a de história, disciplina essa que serve como primazia para o sucesso das demais, devido suas implicações. Tal disciplina é colocada como coadjuvante e seu método de aprendizagem onde o foco é o professor e detentor de todas as informações, e o livro didático como base, chegando a ser o único instrumento utilizado para lecionamento das aulas.

Verificando, o quanto o ensino de história e dos conteúdos dessa área do conhecimento são irrefutáveis para o crescimento dos indivíduos, fez-se necessário desbravar como a ministração das aulas e os recursos tecnológicos são componentes chaves para que os alunos não se restrinjam a saberes mutáveis e as datas, ou figuras contidas nos livros seja o único aparato para análise e visualização desses. 


\subsection{Metodologias ativas no ensino de história}

O mundo fora marcado por intensas transformações, haja visto que as maleabilidades das situações estiveram corriqueiramente percebidas na vida dos indivíduos, nas situações mais simplórias, pois a globalização e a tecnologia são eixos que conduzem essa nova sociedade da liquidez.

Destaca-se nessa ótica, que as inserções das metodologias ativas não são inovadoras, uma vez que Emílio de Jean Jacques Rousseau (1712-1778) já havia tecido estudos em relação a prática ser mais contundente para a exploração de conhecimentos. Assim, ela necessita apresentar características e vivências em que o aluno seja o centro do processo. (Abreu, 2009).

Fora perceptível ainda que na Escola Nova propagada por Anísio Teixeira no Brasil, discípulo de Jhon Dewey já demonstrava em seus estudos a importância de dispor as vivências dos alunos como mecanismos preponderantes na construção de saberes.

Alinhada a essa concepção de experiências, o professor é mediador nessa vertente, sabendo-se que o mesmo não necessita reproduzir os fatos, os conceitos que já foram escritos, na medida em que estes são colocados para serem interpretados, trazidos para os contextos dos educandos, de um modo mais enfático para a vida. As aulas de cunho expositivo não podem ser ministradas de forma rotineira. É imprescindível que as aulas sejam orientadas, os alunos motivados a aprender e superar suas dificuldades, através de planejamentos concernentes com as singularidades dos educandos. (MÓRAN, 2008).

Nos livros didáticos de história trabalha-se muito com a questão de imagens, por isso, é preponderante utilizar esse recurso através de aparelhos midiáticos, como é caso dos retroprojetores, das imagens em 3D no próprio celular dos educandos, ou até mesmo do professor, de modo que estes compartilhem seus pontos de vista e suas percepções, a partir daquela imagem gerada e projetada.

Esse realce da imagem como recurso pedagógico fora incorporado nos documentos oficiais que regem a orientação do ensino de história, isto é, os PCN (PARÂMETROS CURRICULARES NACIONAIS). (BEZERRA, 2006).

Segundo Brasil (1997), os PCNs não são sugestões impostas regem-se como caminhos provenientes da coordenação das disciplinas com aspectos didáticos dinâmicos. 
Nesse eixo os objetivos gerais dos anos iniciais do ensino fundamental de história pautam-se, na caracterização de Zucchi (2012, p.22-23) em:

- Comparar acontecimentos no tempo e no espaço, tendo como referência anterioridade, posterioridade e simultaneidade;

- Reconhecer algumas semelhanças e diferenças sociais, econômicas e culturais, de dimensão cotidiana, existentes no seu grupo de convívio escolar e na sua localidade;

- Reconhecer algumas permanências e transformações culturais nas vivencias cotidianas das famílias, da escola e da coletividade, no tempo, no espaço de convivência;

- Caracterizar o modo de vida de uma coletividade indígena, que vive ou viveu na região, distinguindo suas dimensões econômicas, socais, culturais, artísticas e religiosas;

- Identificar diferenças culturais entre o modo de vida de sua localidade e o da comunidade indígena estudada;

- Estabelecer as relações entre o presente e o passado;

- Identificar alguns documentos históricos e fontes de informações, discernindo algumas de suas funções

Com a descrição desses objetivos observa-se que o estudo de história, intermediada por uma ótica em que coloque a realidade dos alunos nessa metodologia, como por exemplo, a história de sua cidade, de seu bairro, observando aspectos que ainda perduram com o tempo e outros que passaram por transformações, em que os alunos possam recontar e recriar cenários com entrevistas de moradores e personalidades que fazem ou fizeram parte desse enredo histórico. Buscando reconhecer os indivíduos que primeiramente povoaram seus bairros. Uma aula em que todos os alunos possam participar com ativismo. As tecnologias se abrangidas com essas finalidades de captar e ajudar tais produções desmistificará que a história pode ser vivida no contexto atual sem perder suas particularidades e seus objetivos primordiais que são difundir os contextos e não possibilitarem de serem marginalizados pelo tempo.

Outra ênfase que não pode ser rechaçada na implementação das metodologias ativas que o ensino de história no ensino fundamental almeja são evidenciados através das Leis no: 10693/2003 e 11645/2008. A segunda em substituição a primeira lei.

A lei 10693/2003 tornou obrigatório o ensino de história e da cultura África e da cultura afro-brasileira, a de 11645/2008 amplia mais, posto que, inclui também a cultura dos indígenas brasileiros. (ZUCCHI, 2012).

As referidas leis transferem a responsabilidade que a escola possui em propor aspectos inovadores para que essa inclusão e a desconstrução de estigmas 
preconceituosos sejam destruídos, o uso de computadores, celulares, tablets, TVs, rádios em que movimentem os alunos nessa ruptura com a imutabilidade.

As disciplinas humanas e sua natureza diversificada, uma vez que focaliza a subjetividade do indivíduo e suas sugestões necessitam refletir acerca do uso das tecnologias no âmbito diagnóstico, como por exemplo, a história. (RODRIGUES, 2015).

Ainda na instância dos PCNs, é registrado que tais orientações visam a formação do aluno como ser ciente dos seus direitos e deveres (MAGALHÃES,2003).

É imprescindível que os objetos tecnológicos alcancem o desenvolvimento satisfatório dos indivíduos e essa aproximação com as disciplinas com teor intelectual semelhantes.

Uma gama de fatores que abrangem essa verificação, diz respeito à organização da subjetividade dos alunos, de modo que estes ampliem seus saberes de história, resultando assim, a crítica no âmbito de atividades como provimento de seminários, onde o professor subsidiará os alunos para o trabalho em equipe. $O$ objetivo nesse caso versará na análise do discurso e na potencialidade dos alunos em propor o conteúdo estabelecido. (RODRIGUES, 2015).

A aprendizagem envolverá a reflexão contínua dos alunos, uma vez que, estes serão sujeitos dos saberes que Ihes serão transmitidos. Permitindo que os conteúdos de história mergulhem na pesquisa das conexões significativas com outras áreas do conhecimento. 


\section{MATERIAL E MÉTODOS}

\subsection{Tipo de pesquisa}

A pesquisa consiste em um dos passos essenciais na construção e reconstrução de saberes. É através dela que se encontra embasamentos teóricos capazes de ressignificar conceitos e vislumbrar aspectos até então desconhecidos e capazes de subsidiar a transformação de contextos desfavoráveis a disseminação de conhecimentos significativos.

Em cima disso, Rudio (1980, p.9) afirma que a pesquisa cientifica "é um conjunto de atividades orientadas para a busca de um determinado conhecimento." Atividades essas que norteiam os estudos acerca de um determinado problema. Auxiliando assim, em todas as decisões que serão tomadas para a reflexão e intervenção da temática analisada.

Partindo desses pressupostos, a metodologia utilizada para o referido estudo fundamenta-se quanto aos objetivos na pesquisa exploratório-descritiva e pesquisa bibliográfica, em relação a sua abordagem quali-quantitativa.

Com relação à pesquisa exploratório-descritiva pretende-se propiciar a estreiteza com o fenômeno analisado, haja vista que a partir dessa investigação serão possíveis visualizar mais ampla a temática, a fim de tecer aspectos relevantes para que o referido estudo encontre mais exatidão em suas indagações.

A pesquisa exploratória descritiva focaliza no aprimoramento de tentativas para confirmar ou rechaçar ferramentas, permitindo ao pesquisador mais aproximação com o tema enfatizado. Relaciona-se a primeira fase de uma pesquisa mais intensa, e é comumente utilizada em temas até então pouco discutidos e exploradas, para que se consiga adentrar de maneira mais. Generalizada. (GIL, 2002).

No que tange a sua abordagem de cunho quali-quantitativa será indispensável tendo em vista que além dos pesquisadores relatarem em palavras e apontar significâncias, eles vão utilizar os números para mensurar a importância do estudo realizado.

Consoante destaca Gonzaga (in: PIMENTA, GHEDIN E FRANCO, 2006, p.73): 
Na pesquisa qualitativa, o pesquisador vê o cenário e as pessoas, a partir de uma perspectiva holística; as pessoas, os palcos ou os grupos não são reduzidos a variáveis, senão consideradas como um todo. Assim o pesquisador qualitativo estuda as pessoas no contexto de seu passado e das situações nas quais se acham.

Segundo Richardson (2008, p.70), a pesquisa quantitativa "caracteriza-se pelo emprego da quantificação, tanto nas modalidades da coleta de informações quanto no tratamento delas por meio de técnicas e estatísticas."

As duas abordagens foram indispensáveis para que a referida pesquisa alinhasse tanto a forma holística de se buscar dados, como a forma quantificada.

Ilustrando essa concepção, Malhotra (2001) e Laville e Dionne (1999) afirmam que tal abordagem é complementar, auxiliando de forma mútua no processo que se preconiza.

\subsection{Local de pesquisa}

O presente estudo sucedeu-se em uma instituição escolar municipal da rede pública de ensino, a Unidade de Ensino Fundamental Balbina Carvalho, situada na Rua Praça Miguel Cunha, SN, Bairro Trizidela / Bacabal-MA.

\subsection{Sujeitos da pesquisa}

Visando atender os objetivos elencados no estudo, a população compreendeu-se num total de 75 alunos, onde foram envolvidos na proposta como amostragem 22 desses alunos.

\subsection{Caracterização da escola campo}

A pesquisa foi realizada na Unidade de Ensino Fundamental Balbina Carvalho, situada no Bairro Trizidela, SN, zona Urbana de Bacabal-MA, no período de 15 de Maio à 21 de Junho de 2018. Refere-se a uma Instituição de Ensino Público municipal. A sua localização é evidenciada pela violência exorbitante, onde os índices de criminalidade assolam os moradores de modo assustador, em que as formas interventivas são sempre acolhidas e prestigiadas pelos espaços 
promovedores de melhoria de vida da população, dentre elas, as Escolas e os projetos Educativos.

No que tange a sua trajetória histórica, em março de 1987 iniciou-se o processo de ensino aprendizagem neste arranjo estimulador de saberes que nos seus primeiros anos funcionavam em um galpão cedido pela própria comunidade, recebendo como nomenclatura Unidade de Ensino Associação de Moradores do Bairro Trizidela.

A matrícula pioneira contou com um total de cento e cinco (105) alunos racionados em dois turnos, matutino e vespertino, e três turmas: duas de $1^{\text {a }}$ série e uma de $2^{a}$ série. As primeiras docentes chamavam-se Rosimar Monteiro dos Santos e Rosilene Oliveira Araújo Sousa. Já por volta dos anos 2000, para que os docentes e discentes pudessem ter mais comodidade e conforto, a instituição passou a exercer suas funções num prédio alugado, ao passo que o contingente de alunos aumentou. Em 2001 passou a desenvolver suas atividades nos três turnos: matutino, vespertino e noturno. Em 31 de Julho ainda de 2001, foi sancionada e aprovada a Lei de número 913/2001, que alterava o nome da Escola para Unidade de Ensino Fundamental Balbina Carvalho, em condecoração a uma moradora do bairro, já falecida, na qual desempenhou por um período extenso a profissão de parteira do bairro, tendo papel de destaque para aquela comunidade, haja vista, que contribuiu para o nascimento de muitas crianças.

Em 17 de Abril de 2002 foi cedido à comunidade do bairro, o enfatizado o prédio educacional constituído de (03) três salas de aula, uma (01) secretaria, dois (02) banheiros, uma (01) cozinha, uma (01) pátio e (01) laboratório de informática, que nunca fora utilizado em decorrência da não instalação dos computadores. Logo, os computadores retornaram a Secretaria Municipal de Educação (SEMED). Hoje o laboratório em questão passou a ser um (01) depósito da escola. Tal construção fora executada pela Prefeitura Municipal, na figura do Gestor José Vieira Lins e seu secretário de Educação Sr. Francisco Alcir Coutinho.

Ainda acerca da caracterização do perfil da comunidade do bairro é de baixo poder aquisitivo e que sobrevivem, em sua grande maioria pela pesca (por tratar-se de comunidade ribeirinha, as margens do rio Mearim e das olarias na fabricação de tijolos.

Tendo em vista que a sociedade vigente é regida pela alavancagem do capitalismo, onde o ter, o consumo exacerbado prepondera-se diante do ser, e de 
valores, a comunidade em questão permeia-se pela sobrevivência precária, advinda do esmagamento das práticas capitalistas.

Mediante a essas adversidades que assolam a referida comunidade, a U.E.F. Balbina Carvalho, subsidiada pela Lei de Diretrizes e Bases da Educação Nacional (LDB) № 9394/96, a Constituição Brasileira, Estatuto da Criança e do adolescente (ECA) amparada também pelos PCNs (Parâmetros Curriculares Nacionais), Conselho Estadual do Maranhão e pelo conselho Municipal de Educação de Bacabal-MA, objetiva estabelecer mecanismos, ao passo que os recursos provenientes da educação alcancem a transformação social e melhoria de vida dos cidadãos que abrangem o espaço da comunidade enfatizada.

A sua filosofia de trabalho norteia-se no resgate aos papéis e as significâncias que os estudos incorporam na formação da criança e também do jovem, realizando suas funções de educação na vida dos educandos.

A natureza do Projeto Político Pedagógico da U.E.F. Balbina Carvalho no que concernem os conhecimentos de história tem como pressupostos a aprendizagem dos alunos, através da realidade nas suas diversidades e nas infinitas dimensões temporais. Reiterando ainda os compromissos e as atitudes dos indivíduos, de grupos e nações na reconstrução das sociedades, promovendo estudos das vertentes locais, regionais, nacionais e mundiais, das distinções e semelhanças entre culturas, das mudanças e manutenções da sociedade evidenciada.

Atualmente a Escola dispõe de 139 alunos nos três turnos, (06) professores, (01) coordenadora pedagógica, (01) diretora, (01) secretária, (04) vigias, (03) ASG (Auxiliar de Serviços Gerais). Em sua estrutura física contém (03) salas de aulas, (01) depósito, (01) cantina, (02) banheiros, (01) diretoria. Com relação a seu espaço físico não privilegia uma ornamentação viabilizadora de atividades pedagógicas, haja vista que o pátio da escola é estreito e pouco abordado na recreação e interação dos alunos. Ressalta-se ainda, que a escola possuía um laboratório de informática, no qual não fora explorado, logo, atravessou a extinção.

Focaliza- se ainda, que a instituição não oferece climatização, a ventilação e a iluminação são comprometidas. As aulas são lecionadas em salas escuras. As salas são pequenas para o número de alunos que comportam.

A sala em estudo do $5^{\circ}$ ano tem em sua matricula 30 alunos, onde 22 são frequentes, os demais passam pela evasão escolar. 
Os materiais escolares, no que tange a inserção de jogos, tecnologias, são pouco estimulados, haja vista que a mesma possui (01) retroprojetor, (01) televisão, (01) computador, (01) impressora. Ferramentas essas que não são abordadas na conjectura das ações pedagógicas.

O lanche escolar é oferecido diariamente, alimentação essa que na maioria das vezes é a primeira refeição que aquelas crianças recebem.

A metodologia aplicada na escola é baseada no método construtivo, onde seu planejamento é mensal. Fomenta- se também que o espaço escolar se alicerça na formação humana em suas instâncias mais elevadas, visto que o papel da Educação é propor condições para que os indivíduos atinjam a harmonização social para que a sociedade logre o êxito.

\subsection{Instrumento de coleta de dados}

Para a efetivação do referido estudo, apresentou-se um termo de consentimento livre e esclarecido (TCLE), de acordo com o que é defendido pela Resolução 466/12,que consiste na pesquisa realizada com ser humano (APÊNDICE A) aos membros envolvidos na pesquisa. A liberdade em que tais sujeitos tiveram para prosseguir ou desistir das atividades e ações empreendidas, além de discrição total dos dados que constituem cada participante merecem ser enfatizadas. Elaborou-se ainda termo de consentimento livre e esclarecido aos pais no (APÊNDICE B) onde os mesmos permitiram a realização das atividades com seus filhos, haja vista que a pesquisa fora desempenhada com crianças. Posterior a autorização incorreu-se à coleta de dados na qual empregou como instrumentos: observação participante, pesquisa bibliográfica, questionário (APÊNDICE C) aplicado com os discentes, regidos de perguntas fechadas, priorizando o sigilo das respostas e da identidade dos sujeitos, e pesquisa-ação.

A coleta de dados foi subsidiada por intermédio de observações, livros, periódicos e atividades pedagógicas. Ações reflexivas de tomada de decisão serão promovidas pelas pesquisadoras, ao passo que ocorreu uma relação mais intrínseca entre as pesquisadoras e a problemática.

A observação consiste num dos pontos iniciais para que se delineie o estudo, uma vez que é a partir dessa observância que o pesquisador(es) passam a ter um contato mais direto com o fenômeno investigado, contudo sem interferir nas ações 
que estão sendo visualizadas. Ela ajuda o pesquisador a "identificar e obter provas a respeito de objetivos sobre os quais os indivíduos não têm consciência, mas que orientam seu comportamento". (MARCONI e LAKATOS, 1996, p.79).

Conforme Xavier (2012, p.48) a pesquisa bibliográfica é entendida como:

[...] aquela forma de investigação cuja resposta é buscada em informações contidas em material gráfico, sonoro ou digital estocadas em bibliotecas reais ou virtuais. O pesquisador faz um levantamento de trabalhos já realizados sobre um determinado tema e cataloga-os a fim de rever, reanalisar, reinterpretar e criticar procedimentos técnicos e pontos de vista teóricos considerados pelo autor da pesquisa já envelhecidos" ou ineficientes.

O questionário apresenta-se como outra ferramenta indispensável para a coleta de dados, uma vez que os indivíduos investigados responderão perguntas elaboradas pelos próprios pesquisadores objetivadas a auxiliar numa melhor apreensão dos aspectos que norteiam o estudo.

Reiterando isso, Cervo \& Bervian (2002, p.48) falam que o questionário "refere-se a um meio de obter respostas às questões por uma fórmula que o próprio informante preenche". Sendo vantajoso por abarcar um número maior de participantes e de padronizar os dados, tornando-os mais amplos para se chegar a uma compreensão.

Foi utilizado o questionário com perguntas fechadas produzidas pelas pesquisadoras advindas das inquietações provenientes da temática, a fim de refletir e sugerir operações de melhorias para o prazer e a aprendizagem dos alunos, através do enfoque em estudo.

Outro tipo de coleta de dados fundamental para a o encaminhamento desse estudo, centra-se na pesquisa-ação, tendo em vista que o trabalho foi imbricado numa proposta pedagógica, a fim de reconhecer um problema e traçar mecanismos para que este venha a ser solucionado.

Nesse sentido os teóricos dispõem:

Pesquisa-ação é uma forma de investigação baseada em uma autorreflexão coletiva, empreendida pelos participantes de um grupo social, de maneira a melhorara a racionalidade e a justiça de suas próprias práticas sociais e educacionais, como também o seu entendimento dessas práticas e de situações onde essas práticas acontecem. A abordagem é de uma pesquisa ação apenas quando ela é colaborativa. [...] (KEMMIS E MC TAGGART, 1988, apud ELIA e SAMPAIO, 2001, p. 248). 
Ainda nesse sentido, Thiollent (2007, p. 14) define:

[...] é um tipo de pesquisa social com base empírica que é concebida e realizada em estreita associação com uma ação ou com a resolução de um problema coletivo e no qual os pesquisadores e os participantes representativos da situação ou do problema estão envolvidos do modo cooperativo ou participativo.

Analisando os aspectos norteadores da pesquisa-ação percebeu-se que a mesma se apresentou como o tipo mais apropriado para a execução dos estudos estabelecidos.

A proposta foi norteada mediante objetivos precisos acerca do tema discutido, ansiando disponibilizar e propor soluções que refutem as práticas de memorização nas aulas de história e da passividade que os alunos vivenciam na aquisição dos saberes escolares.

Desenvolveu-se assim, uma compreensão alicerçada nas informações levantadas no questionário, nas práticas pedagógicas que foram desenvolvidas propiciando assim visões holísticas e sensibilizadoras quanto à promoção de metodologias que perpassem o tradicionalismo, oferecendo para os educandos possibilidades de construir e reconstruir conceitos e fatos históricos a partir do dinamismo que as mídias digitais concebem. Averiguando assim, a relação que atividades sugestivas provocam no ambiente escolar e na melhoria da escola, no que diz respeito tecnologia na sala de aula, e nos conteúdos de uma das disciplinas mais fascinantes que existem, atravessando os muros escolares e transportando para a vida dos alunos, fazendo com que estes viajassem por diferentes épocas e compreendessem o seu entorno, mediante a aproximação que a tecnologia de informação proporcionam.

\subsection{Análise dos Dados}

No que diz respeito, a apresentação dos dados encontrados com a pesquisa corroborou a tabulação e interpretação dos resultados. Sua organização seguiu-se por meio de gráficos em pizza, nos programas da Microsoft Word 2016 e Microsoft Excel 2016 e PowerPoint 2016. 


\section{RESULTADOS E DISCUSSÕES}

Neste capitulo pretende-se discorrer as informações que foram averiguadas, através dos questionários aplicados para a coleta de dados na Unidade de Ensino Fundamental Balbina Carvalho, escola que atende alunos do Ensino Fundamental nos turnos matutino e vespertino e a EJA (EDUCAÇÃO DE JOVENS E ADULTOS), situada na zona urbana da cidade de Bacabal-MA. Será relatada a análise preconizada pelas informações obtidas, em decorrência dos questionários que os discentes responderam. Para promover uma melhor narração detalhada das respostas geradas, tais resultados subsidiarão pela organização de gráficos em pizza, indicando a porcentagem das indagações sequenciadas dos gráficos 1 ao 13.

\section{ANÁLISE DO QUESTIONÁRIO APLICADO AOS DISCENTES}

\section{Gráfico 1 - Tem acesso à internet?}

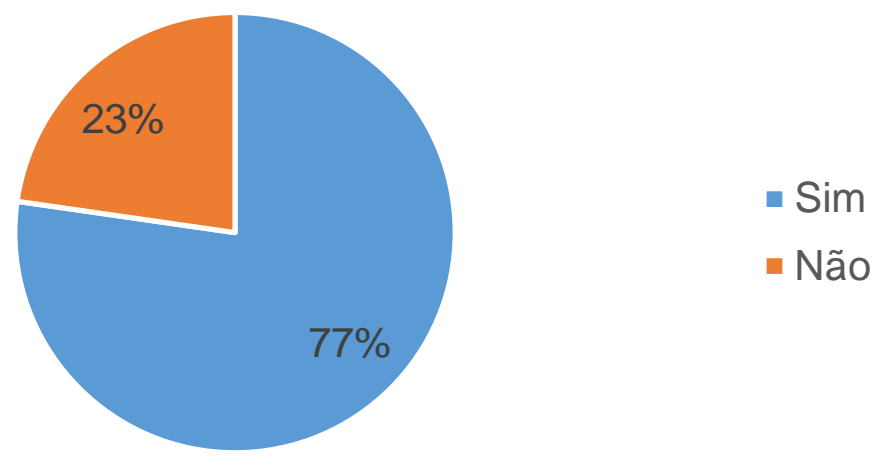

Fonte: pesquisa das autoras (2018).

Segundo o gráfico um, (77\%) dos alunos entrevistados possuem acesso à internet, enquanto que (23\%) não dispõem desse acesso.

O resultado obtido reforça a contingência elevada de indivíduos, em especial de crianças, haja vista que os entrevistados possuem entre 10 e 12 anos na qual estão dispondo de mecanismos de comunicação para adentrar no mundo da tecnologia. Nessa análise percebe- se, que esses alunos podem dialogar com os ramos dos saberes e utilizar essa conexão com a internet, nas situações corriqueiras de sua vida. 
Reiterando essa percepção Behrens (2008, p. 99) infere:

O uso da Internet com critério pode tornar-se um instrumento significativo para o processo educativo em seu conjunto. Ela possibilita o uso de textos, sons, imagens e vídeo que subsidiam a produção do conhecimento. Além disso, a Internet propicia a criação de ambientes ricos, motivadores, interativos, colaborativos e cooperativos.

Com isso, é incontestável que essa extensão da tecnologia se apresenta de maneira satisfatória para que o dinamismo em sala de aula seja desenvolvido. Por isso, já que esta massa de alunos está penetrando nessas infinidades da informatização, faz-se necessário que a mesma seja alinhada da construção dos conhecimentos destes indivíduos. Logo, a escola evidencia-se como estimuladora nesse processo.

Por outro lado, o acesso à internet na escola infelizmente ainda é muito precário e limitado, os alunos em sua grande maioria não usam o wifi da escola, até mesmo os professores não participam dessa configuração. A visão ainda deturpada que o sistema educacional detém, acerca da tecnologia nos entornos da escola provoca essa desconexão entre tecnologia e os conteúdos abordados.

\section{Gráfico 2 - Que meios você utiliza para esse acesso?}

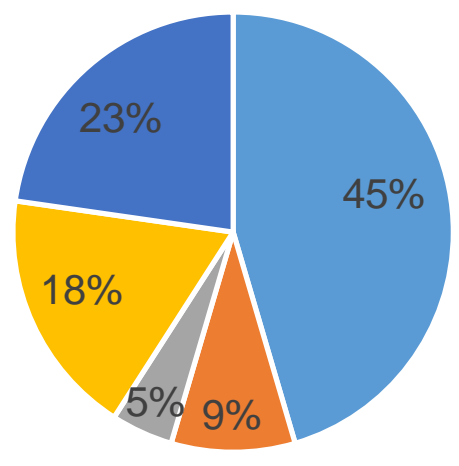

- Celular android

- Tablet

- Computador

- Mais de um dos itens

- Nenhum

Fonte: pesquisa das autoras (2018).

No gráfico dois, os alunos entrevistados relataram que (45\%) deles possuem celular android, (9\%) tablets, (5\%) computadores, (18\%) mais de um dos itens citados e $(23 \%)$ nenhum desses itens. Vários aspectos sustentam a predominância desse dispositivo, haja vista que a praticidade dos celulares androides, em que suas 
funções abarcam desde as mais simples tarefas do dia- a- dia, até mais complexas como comunicação real com pessoas que estão à distância de países com outras. $O$ celular tornou-se uma ferramenta atrativa e dinâmica, em que propiciou uma maior aproximação entre as pessoas, seja por uma curtida de uma foto, ou até mesmo por uma chamada de vídeo. Outro fator incorre nos preços, que foram ficando mais baratos, haja visto, a quantidade de modelos e opções que existem. Tal resultado corroborou ainda mais, que mesmo o poder aquisitivo dos educandos não sendo tão elevado, mas de classe baixa, a vivência que estes possuem com os aparatos tecnológicos é possível preponderante, pois o percentual de alunos com aparelhos celulares superou as expectativas estabelecidas nos primórdios da pesquisa. Constatou-se ainda, que outras ferramentas como tablets e computadores também são abrangidos na vida daqueles alunos.

Em cima dessas constatações, faz-se necessário que o ambiente escolar adeque-se a esses fatos, para que o processo de culminação do saber não seja ultrapassado e desperte a realidade destes indivíduos. Necessita-se, assim, que as aulas provoquem a utilização dessas ferramentas a seu favor, onde aluno e professor sintam-se interligados pela dinâmica que esses apetrechos concebem na vida escolar. Destacando ainda, que as disciplinas, um tanto estáticas, pela grande maioria do sistema, como é o caso da história, seja protagonista nessa ótica das mídias digitais e suas contribuições.

De acordo com Torres (2009, p.393), classifica-o como um "celular que oferece recursos avançados similares aos de um notebook". Os celulares smartphones são conhecidos pela potencialidade inteligente que estes norteiam em sua estrutura.

Levando em consideração essas afirmativas, é de suma importância como os recursos tecnológicos acarretam a personalização necessária para os caminhos de ensino aprendizagem. 


\section{Gráfico 3 - Sabe conceituar as TICs?}

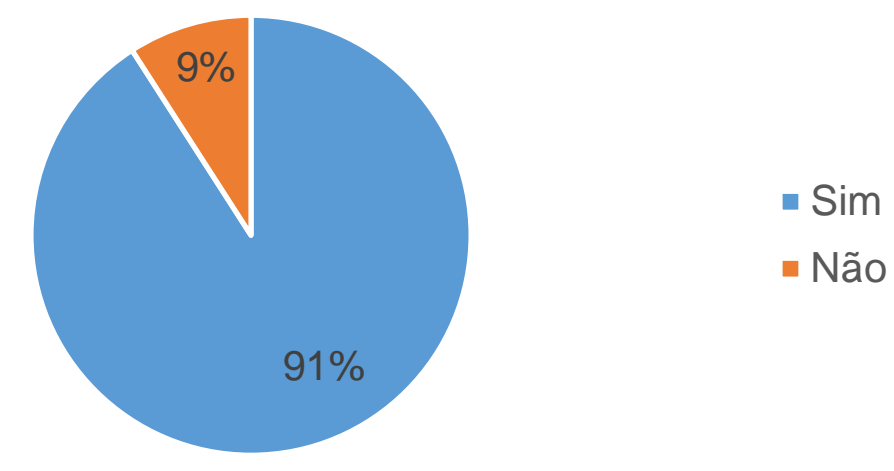

Fonte: pesquisa das autoras (2018).

Verifica-se no gráfico três que, (91\%) dos alunos indagados sabem conceituar as TICs, e (9\%) afirmam não saber conceituá-las. Ressalta-se nessa pergunta que a mesma fora realizada após os esclarecimentos tecidos e as ações empreendidas sobre essa temática. Com isso, a intenção proposta fora alcançada, uma vez que um percentual grandioso dos alunos declara que conseguem descrever o que são as tecnologias de informação e comunicação.

Resultado esse bastante enfático para o prosseguimento do projeto, tendo em vista que a inserção dessas tecnologias de informação no ambiente escolar passa de forma decisiva pela postura e desempenho dos alunos nas abrangências que esta temática possibilita.

É de grande destaque averiguar que os alunos, em decorrência da temática desenvolvida, conseguem conceituar esse assunto tão frequente na vida das pessoas e colaboradora do cumprimento de tarefas indispensáveis para a sociedade.

Bacich, Neto e Trevisani (2015, p.47) fomentam nesse sentido:

Crianças e jovens estão cada vez mais conectadas as tecnologias digitais, configurando-se como uma geração que estabelece novas relações com o conhecimento e que, portanto, requer que transformações aconteçam na escola.

Essa sintonia que essa geração possui com esse novo cenário de comunicação adotado pela presença maciça que a tecnologia promove faz com que 
as escolas utilizem em seus espaços tais ferramentas, posto que os alunos devam ser protagonistas de suas apreensões intelectuais e de sua formação.

Gráfico 4 - A professora utiliza as TICs nas aulas de história?

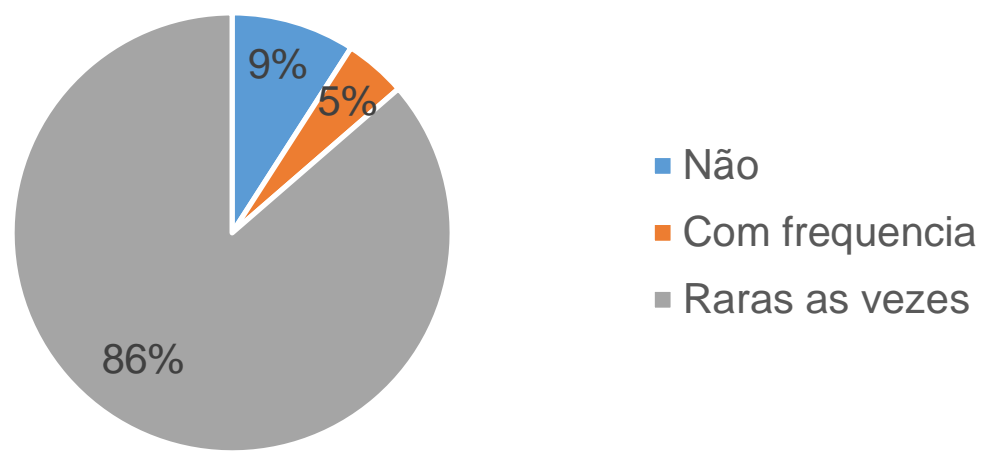

Fonte: pesquisa das autoras (2018).

No gráfico quatro, (86\%) dos alunos entrevistados citaram que raramente a docente utiliza as TICs nas aulas de história, (9\%) disseram que a mesma não utiliza, e outros (5\%) consideram que a mesma faz uso com frequência dessas ferramentas nas aulas de história. Analisa-se com esses números que infelizmente a sala de aula, com destaque para o lecionamento de disciplinas fundamentais para a propagação de novos saberes, e de reconstrução de ideais, como é o caso dos efeitos da disciplina de história, ainda não convergem com esse perfil de aluno conectado e autônomo que o mundo requer. Dados esses que constatam que,a sensibilização, a ruptura com práticas tradicionais e mecânicas condicionam os alunos a sentirem-se estimulados e envolvidos nessa vertente de protagonismo

É notório que assimilamos de forma mais clara, ao passo que ocorra significâncias para as nossas teorias, para aquilo que buscamos definir, é necessário haver sentido nesse percurso. Mesmo sabendo que nesse trajeto existirão inúmeras dúvidas e divergências, as mesmas amparam o entendimento do nosso presente, passado, como também nas pretensões do nosso futuro, destacando assim a significância que o ensino de história personalizado agrega nesse arranjo. (MÓRAN, 2015). 
Gráfico 5 - Os conteúdos de história tornam-se mais claros quando se utilizam algum recurso tecnológico?

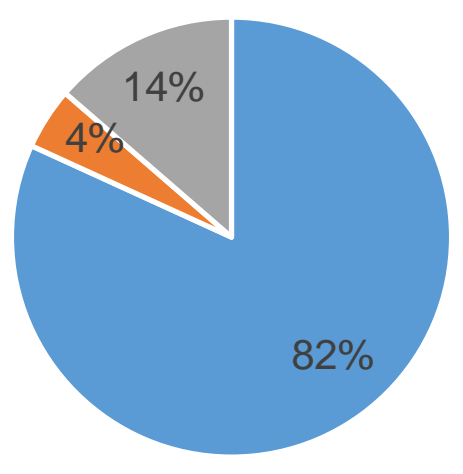

\author{
- É mais fácil \\ assimilar com eles \\ - Não contribuem \\ em nada \\ - Só servem para \\ passar tempo
}

Fonte: pesquisa das autoras (2018).

Constatou-se de acordo com o gráfico cinco que, os conteúdos de história tornam-se mais claros, quando se utilizam algum recurso tecnológico, onde (82\%) dos alunos entrevistados disseram que é mais fácil de assimilar com eles, outros (14\%) declararam que só servem para passar o tempo e (4\%) responderam que não contribuem em nada.

Partindo desses pressupostos numéricos, é perceptível que a abordagem de aparelhos midiáticos e digitais na disseminação de saberes, essencialmente quando estes provem de disciplinas até então estáticas, os resquícios positivos são ainda mais consideráveis, visto que a disciplina de história é marcada na pela memorização de datas e nomes de personagens que protagonizaram períodos, ausente até então da maleabilidade e ressiginificância para reorientar e compreender os contextos em posições holísticas.

Levando em questão essa assertiva, Goodson, (2007, p.250) corrobora:

\begin{abstract}
Ver a aprendizagem como algo ligado a história de vida é entender que ela está situada em um contexto, e que também tem história- tanto em termos de histórias de vida dos indivíduos e histórias e trajetórias das instituições que oferecem oportunidades formais de aprendizagem como histórias de comunidades e situações em que a aprendizagem informal se desenvolve.
\end{abstract}

Logo, quando os assuntos de história são desenvolvidos através de mecanismos tecnológicos concernidos com a dinâmica da aprendizagem dos 
educandos é mais favorável para que estes aprofundem os saberes e compreendam as teorias de maneira mais enfática.

Gráfico 6 - Quando a professora solicita a pesquisa de temas de história, você recorre à internet?

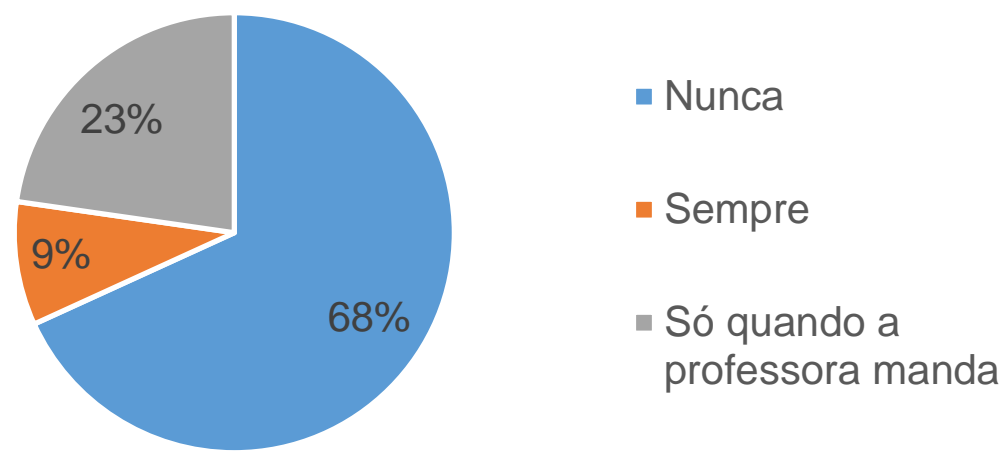

Fonte: pesquisa das autoras (2018).

De acordo com o gráfico seis, (68\%) dos alunos entrevistados não recorrem à pesquisa via internet quando Ihes são solicitadas pesquisas dos temas de história, (23\%) destes só pesquisam quando a docente impõe a pesquisa via sites e somente (9\%) responderam que sempre recorrem à internet para compreensão dos temas de história.

Mediante esse deslindamento é incontestável aferir que um número irrisório de alunos adere às tecnologias para buscar a compreensão dos assuntos de história, uma vez que esse alinhamento entre educação e mídias digitais são indissociáveis. Sendo assim, esse elo entre as práticas educativas dos conhecimentos de história e a inserção de ferramentas tecnológicas, influenciam diretamente no envolvimento que os alunos terão nessa perspectiva.

$O$ mundo em sua mais recente estrutura propõe que os professores promovam questionamentos e discussões, produzindo o protagonismo dos alunos, mediando em todo transcurso, os jovens, na medida em que estes aprendam de maneira contextualizada, coletiva e individual. Redesenhando assim os horizontes. Essas mudanças não podem atrelar-se a mesmice, mas a inovação conquistada, a inspiração e o encantamento por aprendizagens favorecedoras da autoria dos 
próprios alunos, principalmente na disciplina de história, haja visto que esta é baluarte para absorção das demais. (Lima e Moura, 2015).

Gráfico 7 - Se utiliza a internet limita-se a apenas o primeiro site que vê para finalizar a pesquisa?

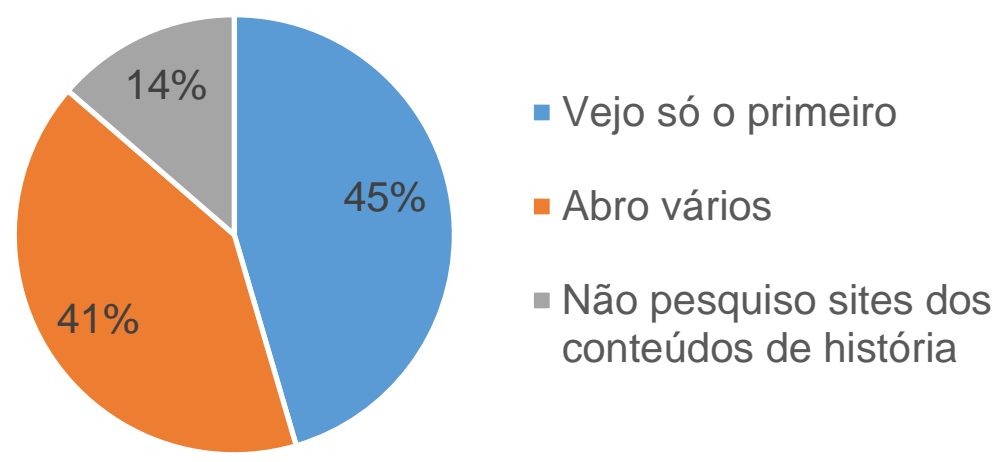

Fonte: pesquisa das autoras (2018).

A partir da reflexão do gráfico sete, delineia-se que os alunos recorrem aos sites de história para fazerem as pesquisas dos assuntos explanados de história, uma vez que $(41 \%)$ dos alunos entrevistados disseram que abrem vários sites para aprofundamento das temáticas de história. Entretanto de forma negativa (45\%) afirmaram que finalizam a pesquisa logo no primeiro site que abrem. Já (14\%) relataram não pesquisar sites de conteúdos de história.

Em decorrência das ponderações tecidas no projeto percebeu que essa disseminação das tecnologias de informação e comunicação está em ascensão na Educação e adentrando de maneira engatilhada para o sucesso que o sistema de ensino busca, isto é, a engrenagem de munições cognitivas para o despertar de alunos participantes e indagadores nos vários contextos históricos que estes incorrerem.

Em cima dessa abordagem, Nascimento (2015) frisa que o espaço escolar deve sintonizar as crianças a esse acesso, de forma que o ensino híbrido, ou seja, aquele marcado pelas agregações de melhoria do ensino, as adequações dos assuntos sejam facilitadas pelos materiais disponibilizados. Os sites de pesquisas são exemplos de fontes que auxiliam nesse alcance. 
Gráfico 8 - Costuma assistir vídeos, músicas e filmes, novelas sobre os conteúdos de história?

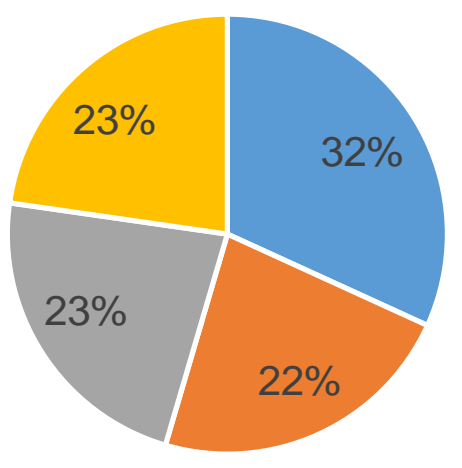

- Sempre

- Nunca

- Só se a professora solicitar

- Só se ela colocar na sala

Fonte: pesquisa das autoras (2018).

A síntese do gráfico oito explicita que a utilização de vídeos, músicas, filmes, novelas são grandes alicerces acerca dos conteúdos de história, haja vista que $(32 \%)$ dos alunos entrevistados citaram que sempre recorrem a esses meios para aprendizagem dessa disciplina e suas implicações, (22\%) destes relataram que nunca executam esses apoios, $(23 \%)$ incorreram que somente se a docente solicitar e outros $(23 \%)$ declaram que somente se a professora colocar em sala de aula.

Os números identificados desencadeiam uma discussão muito fervorosa, no que tange aos rumos que a Educação anseia, posto que se a escola, alinhada as metodologias empregadas reforçam o papel incisivo que a tecnologia está tendo na sociedade em curso. $O$ modelo repetitivo e enfadonho significativamente criticado pelos pensadores e estudiosos que idealizam a que a educação continuará se sobressaindo, através de resultados adversos acerca da aprendizagem como função social quando as metodologias não são colocadas de forma correta.

É importante notar que nem todos os alunos da sala de aula têm a mesma necessidade de aprender ou reforçar determinados conteúdos, logo o professor não pode pensar em aplicar a mesma atividade em um mesmo espaço para todos os educandos ao mesmo tempo. (SANTOS, 2015, p.109).

$\mathrm{Na}$ referida análise, é de grande valia perceber que a absorção de recursos visuais, auditivos nesse processo de transmissão e diálogo de saberes é relevante para que os alunos em suas dificuldades sejam transformados em oportunidades a aprender com o dinâmico, mutável e colaborador de novas aprendizagens. 
Gráfico 9 - A professora utiliza o laboratório de informática nas aulas de história?

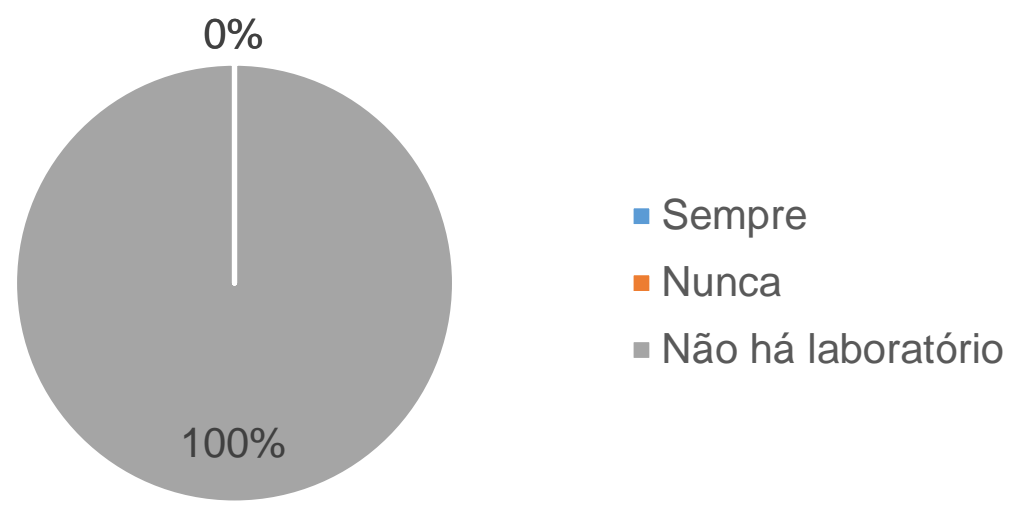

Fonte: pesquisa das autoras (2018).

O gráfico nove infere acerca de um dos assuntos mais discutidos quando se fala de estrutura plausível para que os alunos tenham acesso à tecnologia, isto é, o laboratório de informática, espaço esse que contém em suas perspectivas o contato preponderante que os alunos têm direito de desfrutar. No entanto, a presença de laboratório de informática como ferramenta nas aulas de história, não contempla a realidade dos alunos em destaque, uma vez que (100\%) dos alunos afirmaram que a docente não utiliza o laboratório de história nas aulas de história. Ampliando ainda mais sobre a pesquisa feita, percebeu que essa utilização não ocorria pelo fato da escola não disponibilizar de laboratório de informática. O laboratório até fora criado, mas não houve instalação dos computadores e o mesmo passou a servir como depósito da instituição.

Reafirmando a necessidade que um espaço físico estruturado e com suporte eficaz para 0 ingresso dos alunos nas possibilidades que o conhecimento proporciona, Sunaga e Carvalho (2015, p.142) abrangem: "com o avanço da tecnologia, o futuro da escola se dará pelo estabelecimento de uma rede de conexões em que a aprendizagem colaborativa é o eixo principal."

Quando as aulas são complementadas e até mesmo ajustadas nos laboratórios de informática, percebe-se que a partilha e a dimensão dos conhecimentos construídos são incomensuráveis. 
Gráfico 10 - Antes do projeto a Inserção das TICs no ensino aprendizagem de história já tinha escutado ou lido sobre as TICs?

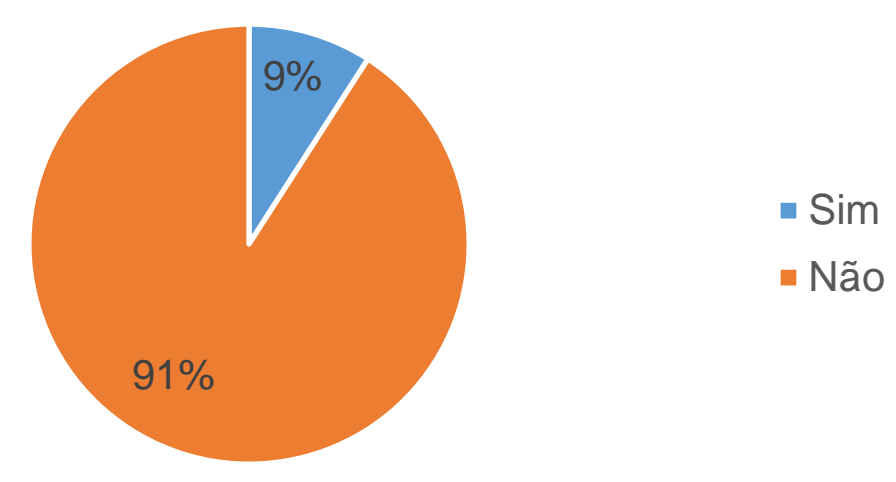

Fonte: pesquisa das autoras (2018).

O apontamento do gráfico dez discorre a respeito de um dos temas mais relevantes na sociedade vigente, uma vez que fala das TICs e os conhecimentos que os alunos possuem acerca desta. Com porcentagem bastante elevada reconheceu o quanto as TICs e sua nomenclatura ainda estão distantes dos discursos escolares, uma vez que $(91 \%)$ dos alunos entrevistados disseram que antes da implementação do projeto enfatizado não tinham escutado nada acerca dessas ferramentas. Um número bastante pequeno discorreu já ter visto falas dessa temática.

Os números assolam ainda mais a necessidade de falar sobre as temáticas mais recorrentes no cotidiano dos alunos, de modo que sejam esclarecidas informações pertinentes a seus contextos, como é caso do próprio celular que é uma TIC, mas que muitos alunos não compreendem a nomenclatura, tendo em visto, que sua própria sala de aula não os deixa interligados com tais fatos e criações que estão em evidências na atualidade.

Ainda nessa consonância, Sunaga e Carvalho (2015, p.143) fomentam que "hoje, é essencial ensinar os estudantes a aprender responsavelmente. O professor passa a ser um tutor, guiando os alunos na busca pelas informações necessárias para seu desenvolvimento".

A aproximação dos alunos com as temáticas atuais e verificação dessas na sua vida disponibilizam aos mesmos recursos mais efetivos para o seu processo de aprendizagem. 
Gráfico 11 - As aulas com o uso das TICs feitas pelo projeto deixaram as aulas de histórias mais prazerosas?

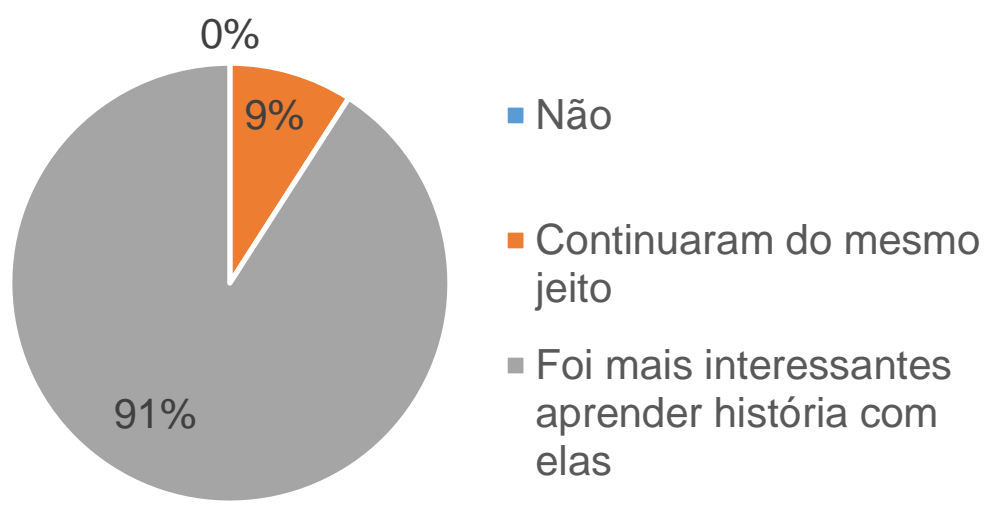

Fonte: pesquisa das autoras (2018).

O gráfico onze é o sustentáculo para que a utilização das Tecnologias nas aulas de história torne-se experiências corriqueiras, uma vez que (91\%) dos alunos entrevistados afirmaram que a utilização das TICs deixou as aulas de história mais prazerosas, $(9 \%)$ disseram que as mesmas continuaram do mesmo jeito e $(0 \%)$ relataram que as mesmas não se tornaram mais prazerosas.

Acerca desses números expressivos que ressignificam e confirmam a importância que as TICs possuem para o afloramento de aulas de história mediadas pelo dinamismo, a significância e a interatividade que estas trazem consigo é inimaginável não falar de um ensino de história favorável as projeções dos alunos, sem que este seja norteado pela tecnologia e seus aparatos de inovação.

A forma como organizamos e administramos o espaço físico de nossa sala de aula constitui, por si só, uma mensagem curricular, reflete o nosso modelo educativo.

[...]. A forma como organizamos os espaços a cada uma de suas áreas e elementos reflete direta e indiretamente o valor que lhe damos e a função que lhe outorgamos e, além disso, diz muito em relação ao tipo de comportamento instrutivo e transmite $O$ que esperamos de nossos alunos(as). (ZABALZA, 1987, p.124).

A concretude que a tecnologia facilita na vida dos alunos e na inferência que estes terão na construção de seus conhecimentos, passa de modo contundente pelo formato de aula e de recursos que os docentes ministram. $O$ gozo que os alunos 
defendem quando as TICs são empenhadas em auxiliar o processo de ensino aprendizagem dos mesmos no que se refere a disciplina de história ressurge com mais veemência o papel que estes dispositivos tecnológicos colaboram para a educação e suas emancipações de aprender pela orientação, mediação e não imposição reprodutora, que grande maioria das docentes executam. Deixando as aulas menos atraentes e distantes do verdadeiro sentido que as imbricações dos fatores históricos incidem.

Gráfico 12 - As TICs nas aulas de história facilitam uma apreensão mais ampla dos conteúdos tratados em sala de aula?

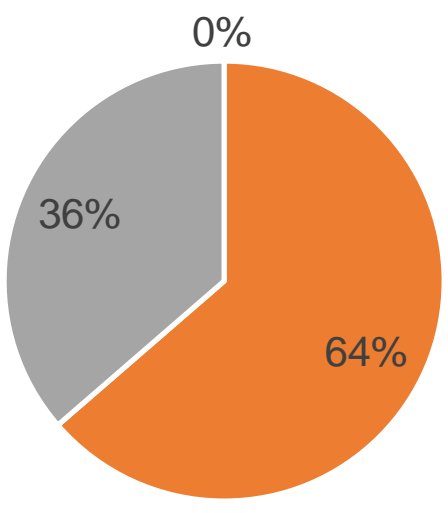

- Não

- Os conteúdos pareciam mais reais

- Os conteúdos tornaramse mais divertidos com elas

Fonte: pesquisa das autoras (2018).

O gráfico doze enfatiza que as TICs nas aulas de história facilitam uma apreensão mais ampla dos conteúdos tratados em sala de aula, uma vez que (64\%) dos alunos entrevistados afirmaram que os conteúdos pareciam mais reais, e os outros $(36 \%)$ disseram que os conteúdos se tornaram mais divertidos.

Os dados condizem com a prevalência que as Tecnologias de informação e comunicação desempenham na vida dos alunos, em destaque para uma melhor assimilação dos conteúdos arrolados. Na sala de aula os alunos ainda são coadjuvantes, seus saberes são restritos. A superioridade dos professores com suas verdades absolutas convergem para que as disciplinas chamadas de instransponíveis por novos pontos de vista, como é caso da história, seja reconstruída e atue pela produção de saberes amplos e investigativos.

O Uso das fotografias como documentos históricos, através da tela dos mais infinitos dispositivos tecnológicos menciona o quão a presença das TICs são 
grandiosas para a construção de aulas de histórias mais reais e concretas, ao passo que os alunos se sentirão voltados para o contexto em que estão norteados.

Em consonância com o pensamento de Silva (2012) exemplificando que a interação e a multidisciplinaridade que os conteúdos de história, com as demais disciplinas, dentre elas, a Língua portuguesa, a Matemática, Geografia, assim como outras, através de pesquisas dos temas que estas possuem em comum. Temas como os índios brasileiros, onde serão pesquisadas tais informações pela internet. Desenvolvendo além da criticidade pela leitura, a cooperação das ferramentas TICs, de modo que serão analisadas diferentes fontes de informação para exploração dos confrontos, distinções e relações entre os grupos indígenas.

Gráfico 13 - Utilizam as TICs para revisar ou complementar os conteúdos de história após o projeto?

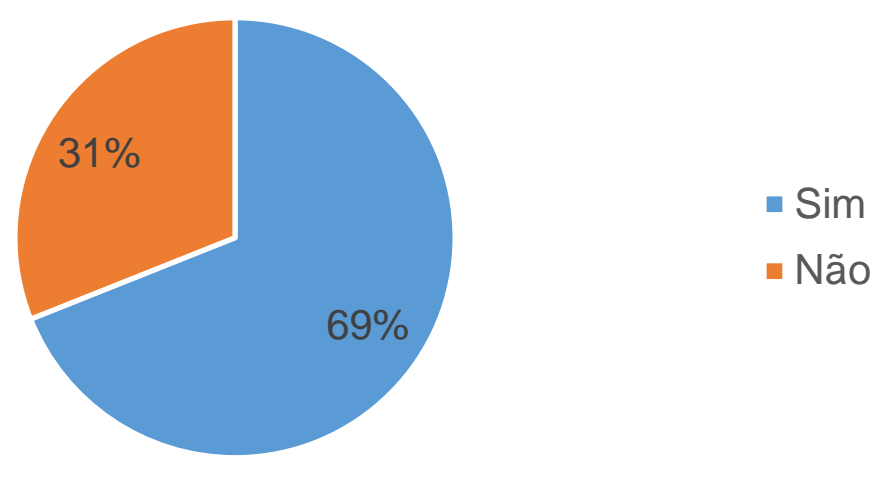

Fonte: pesquisa das autoras (2018).

No gráfico treze, a utilização das TICs para revisar os conteúdos de história após o projeto realçou o papel que as práticas educativas de sensibilização para os assuntos atuais e a disciplina de história então intrinsecamente interligados para a assimilação de aprendizagens significativas e transformadoras que a Educação provoca, isso fora constatado com os percentuais adquiridos, visto que (69\%) dos alunos entrevistados passaram a complementar seus estudos de história, utilizandoas para revisar os conteúdos disseminados, os outros (31\%) disseram não utilizar.

Os números apontam para que a inserção de ferramentas digitais sirva como apoio para que as aulas de história não sejam inferiorizadas pela mutabilidade, mas 
pela construção e reconstrução, a partir de distintas averiguações que a tecnologia propõe.

A problematização de fontes a partir de relatos orais que os alunos podem fazer com as pessoas que norteiam seu bairro, seu entorno escolar são algumas das conjecturas que os aparelhos tecnológicos proporcionam para o divertimento e correlação da realidade dos envolvidos no processo de aprendizagem no ensino de história. (ZUCCHI, 2012). 


\section{PROPOSTA}

\subsection{A INSERÇÃO DAS TECNOLOGIAS DE INFORMAÇÃO E COMUNICAÇÃO NO PROCESSO DE APRENDIZAGEM DO ENSINO DE HISTÓRIA DOS ALUNOSA DA U.E.F BALBINA CARVALHO, MUNICÍPIO DE BACABAL-MA}

\subsection{Justificativa}

O modelo educacional vigente corrobora de modo significativo o papel que as tecnologias de informação e comunicação possuem nas escolas, em especial no processo de ensino aprendizagem dos alunos. Diante dessa assertiva, uma das disciplinais que contribui para o fortalecimento critico dos alunos é a disciplina de história e os conteúdos que esta aborda. Em decorrência desses fatores, os dispositivos tecnológicos e suas ferramentas necessitam colaborar com o lecionamento dessa área do conhecimento indispensável para a compreensão do passado, presente e futuro dos indivíduos, ao passo que se tornem protagonistas do seu entorno e atuem de modo contundente nas situações que lhes são propostas.

Mediante essa visão transformadora que a tecnologia e seus aparatos dispõem para a execução das aulas de histórias, onde os alunos visualizam-se autores de seus enredos e dos acontecimentos que lhes permeiam, traduzindo e redesenhado os fatos históricos que cercaram o mundo, seu país e sua cidade através do uso da tecnologia, como são o caso dos celulares, computadores, tabletes e os recursos que estes apresentam deixando assim os conteúdos de história extremamente ativos e contextualizados.

Quando as aulas são estimuladoras, estas acarretam funções decisivas para aprendizagens de outras disciplinas consideradas principais, mas que de fato são tão importantes como a própria disciplina destacada, haja vista que os conteúdos quando são analisados nas suas mais variadas vertentes, como por exemplo, entender o contexto histórico de um determinado assunto, os autores que se fizeram presentes, a história é preponderante para a articulação de tais conhecimentos.

Por isso, esse novo perfil de alunos que estão sendo desenvolvidos influencia diretamente em estratégias mais eficazes para se dialogar ideias e informações e o uso das TICs traduzem os anseios que a Educação carece no que tange a ministração de aulas dessa disciplina indispensável para a assimilação de conteúdos 
que auxiliam na fomentação da valorização da identidade dos indivíduos, ao passo que estes utilizem a tecnologia em favor abranger a pesquisa como foco, interagindo seus conhecimentos e mostrando que a mobilidade das ideias está a todo vapor, logo, a escola é mola propulsora para que essa ciência incontestável não limite-se somente aos livros e suas reproduções, mas que construa e ressignifique o ensino e aprendizagem.

Diante do que fora exposto, a presente proposta reforça a relevância de aplicar atividades dinâmicas com o uso da tecnologia na aprendizagem de história, na medida em que os educandos despertarão o seu lado investigador e produtor dos assuntos que lhes norteiam, uma vez que a tecnologia é responsável por possibilitar a dialogicidade necessária para tais ações.

\subsection{Objetivos}

\subsubsection{Objetivo geral}

Socializar atividades com os discentes que englobam as Tecnologias de Informação e Comunicação para a apreensão dos conteúdos de história do 5 ano da U.E.F. Balbina Carvalho.

\subsubsection{Objetivos específicos}

- Vivenciar as TICs na aprendizagem dos conteúdos de história;

- Despertar a pesquisa dos fatos históricos locais na rotina pedagógica dos educandos;

- Descrever a contextualização dos assuntos da disciplina enfatizada, através da relação que estes possuem com filmes, novelas e demais mecanismos tecnológicos;

- Localizar os conteúdos de história de forma lúdica e contextualizada com a realidade dos educandos, através do diálogo com blogs e sites educativos. 


\subsection{Atividades desenvolvidas com os discentes}

- Apresentação de aparelhos tecnológicos e suas funções educativas na aprendizagem dos conteúdos de história;

- Manuseio dos discentes com os aparelhos enfatizados;

- Elaboração de slides dinâmicos dos conteúdos estudados;

- Realização de pesquisas de diversas fontes sobre um mesmo assunto de história;

- Gravação de vídeos sobre os aspectos que refletem a cultura africana: Culinária, música, vocabulários;

- Oficina da pesquisa da história local;

- Diálogos pertinentes em sala de aula da utilização das TICs nos diversos contextos que estão inseridos no ensino de história;

- Exibição de filmes dos assuntos de história;

- Exploração de PDFs, Vídeoaulas, Youtube, Google sala de aula, WhatsApp, Facebook, Instagram, Paint, Word, PowerPoint, Pinterest, visando o afloramento dos assuntos de história.

\subsection{Procedimentos metodológicos}

- Reunião com os membros diretivos da instituição escolar para apresentação da Proposta Pedagógica;

- Dialogicidade com os discentes sobre o projeto e as atividades que foram desenvolvidas;

- Observação participante em sala de aula;

- Aplicação das atividades sugeridas, com auxílio de todos os membros que compõem a escola;

- Registro das ações empreendidas;

- Reflexão com os alunos acerca das atividades propostas;

- Culminância da Proposta Pedagógica;

- Ponderações e agradecimentos. 


\subsection{Recursos}

- Celulares;

- Datashow;

- Caixa de som;

- Notebooks;

- Tablets;

- Livro didático;

- Folhas de chamex;

- Pendrive;

- Quadro e acessórios.

\subsection{Avaliação}

Averiguou-se de modo contínuo o envolvimento dos educandos, através de frequências, observações, participações feitas em cada atividade e os questionamentos tecidos, ao passo que serviram como análise das práticas sugeridas.

\subsection{Sugestões}

- Produção de vídeos sobre os conteúdos mais pertinentes de história ao final de cada bimestre;

- Criação de páginas no Facebook, Instagram, e-mails e blogs para que a docente publique textos digitais, vídeos e outros recursos que auxiliem na ampliação dos saberes lecionados, ou através da interação da escola com os alunos para que estes compartilhem as produções de história e a munição de conteúdos que estes podem estar trocando acerca das aulas da disciplina mencionada;

- Pesquisas em plataformas adaptativas para difusão e extensão dos eixos de história, como por exemplo:

$\checkmark$ Moodle: Uma espécie de software liberado, que tem como proposta auxiliar a aprendizagem tanto de forma individualizada, como de forma coletiva. Seu endereço é: www.moodle.org.br; 
$\checkmark$ Geekie: Customiza o lecionar de acordo com as particularidades de cada aluno, permitindo que os docentes se situem de acordo com as especificidades de aprendizagem dos seus alunos. Seu endereço é: www.geekie.com.br;

$\checkmark$ Google Docs: Partilha de documentos digitais entre alunos e professores. Seu endereço é: docs.google.com;

$\checkmark$ Sílabe: Ambiente virtual que promove ao docente abranger em sua aula, os conteúdos em distintas personalizações, uma vez que o mesmo disponibiliza variadas ferramentas para construção de uma aula interativa.Desencadeando aos educandos indagações que acarretam análises particulares. Seu endereço é: www.silabe.com.br;

$\checkmark$ Dipity: Plataforma responsável pela elaboração de linhas do tempo interativas. Uma forma de o professor traçar com seus alunos imagens e palavras chaves que foram decisivas para melhor assimilação do período histórico estudado. Seu endereço é: $\underline{w w w . d i p i t y . c o m . b r}$

$\checkmark$ Youtube Educação: regido de vídeos sobre os conteúdos do ensino básico. Uma forma do docente propor a busca de filmes dos conteúdos de história. Seu endereço é: youtube.com/Edu;

$\checkmark$ Porta curtas: Área destinada a criação de canais com filmes a sua preferência e compartilhá-los.Um mecanismo para organizar uma lista de filmes sobre os conteúdos corroborados em sala de aula. Seu endereço é: portascurtaas.org.br;

$\checkmark$ Padlet: Possibilita a criação de um mural, onde os alunos através do link colem posts.São utilizados geralmente para atrair os alunos no início das aulas sobre a temática a ser desenvolvida. Seu endereço é: pdlet.com;

$\checkmark$ Show me e Educreations: São aplicativos destinados a criação de vídeos aulas. Estão disponíveis na loja de busca por aplicativos, como google play;

$\checkmark$ Youtube: ferramenta que repõe os vídeos na internet, através de aplicativos. Encontra-se nas lojas de busca por aplicativos, como o google play;

$\checkmark$ Era virtual: site que facilita o passeio virtual por vários museus. Deixando os alunos mais próximos com diferentes contextos da história.Seu endereço é: www.eravirtual.org;

$\checkmark$ Povos indígenas no Brasil: repleto de informações acerca da população pioneira do Brasil, isto é, os indígenas. Seu endereço é: pib.socioambiental.org/pt;

$\checkmark$ Socrative: É um aplicativo que tem como finalidade a criação de questionários em tempo real, permitindo o retorno instantâneo das dúvidas.Bastante proveitoso 
para realização de quizz sobre as temáticas de história. Seu endereço é: www.socrative.com;

$\checkmark$ Zaption: Promove a elaboração de perguntas por intermédio de vídeos. Tornando as aulas mais engajadas para apreensão dos saberes aos alunos. Seu endereço é: www.zaption.com;

- Visita a laboratório de informática;

- Aprendizagem de aulas, intermediados pela realidade virtual, favorecendo assim o passeio dos alunos a se reportarem por período da Escravidão, dentre outros. 


\section{CONSIDERAÇÕES FINAIS}

Mediante as situações vivenciadas e os estudos tecidos acerca do englobamento das Tecnologias de Informação e Comunicação no ensino de história, principalmente na aprendizagem personalizada que os alunos conseguem vivenciar, através desses mecanismos desafiadores, sobretudo, regidos de numerosas perspectivas de melhoramento das aulas, que transcenderam a repetição e a memorização. Passando a ocupar o espaço de protagonismo os alunos, em todas as suas etapas que consistem em diálogos para apreensão dos saberes dessa disciplina substancial para a compreensão do contexto emergido e dos contextos que nos antecederam.

Nesse sentido, pôde ser evidenciado que no cenário presente não se pode discursar e nem delinear as aulas, partindo da premissa que o aluno vai ser um mero receptor de conteúdo, mas que este é um construtor de etapas. Ativistas no processo de aprender, os alunos demonstraram ao passo que os saberes foram explorados, intermediados por ferramentas que faziam parte de seu cotidiano, como por exemplo: os celulares, os computadores, os tablets, dentre outras, demonstrando o quão as mídias digitais são substanciais para o ensino. A aprendizagem de história, não mais se figurou como secundária nas aulas, mas como mola propulsora, para que os contextos históricos dos alunos e que os temas das demais disciplinas consumarem-se com uma visão holística.

A interação, disseminada com tais dispositivos tecnológicos transferiu para os alunos formas de pensar e de reconhecer os conhecimentos desenvolvidos a partir de experiências reais, antes desconhecidas e até mesmo rechaçadas. A participação dos escolares nas aulas, posto a indagações pertinentes sobre os temas inferidos, o envolvimento destes em conhecer e mergulhar no alargamento de perspectivas acerca da história despertada pela Tecnologia.

Portanto, fora através dessa visão esperançosa que a referida proposta averiguou o quão é essencial colocar o aluno como protagonista de suas histórias, pelo viés que a história desempenha, uma vez que, parte dos educandos se mostrou entusiasmado em pesquisar assuntos da disciplina narrada, destacando assim, a busca que estes fizeram da história local, onde puderam constatar a dimensão de fontes que a tecnologia possibilita e as inúmeras ferramentas que o celular possui para se abarcar em infinitos conhecimentos. 
Em decorrência desses aparatos imprescindíveis que abarcam a abrangência de novas formas de comunicação entre as pessoas nas instituições sociais, com destaque para a Educação, as ferramentas digitais consistem num dos pilares que mais refletem a imersão da Tecnologia nos espaços escolares, tornando assim, os educandos centros na construção dos saberes.

Logo, a aprendizagem de história essencialmente nos anos inicias do ensino fundamental, é primordial para que sua trajetória de saberes não se restrinja a marcas de tradicionalismo e de inflexibilidade, mas de pesquisas constantes, onde a base do conhecimento seja a busca e o estímulo ao descontentamento às ideias prontas e absolutas.

O perfil do aluno aspirado na sociedade vigente enaltece a prática sobrepondo-se a teoria acabada.

Os alunos necessitam fazer parte do processo, uma vez que as aulas de histórias contemplem, por exemplo, viajar pelo período da escravidão no Brasil, através de programas de computadores, celulares. Para isso, as práticas pedagógicas para a ministração da referida disciplina não precisam mudar-se em sua pretensão geral, mas adequar-se à realidade virtual e a tecnológica que se instaurou com expressiva eloquência. Por isso, o interesse dos alunos para o aprazimento das aulas, passa indiscutivelmente pela condução desta.

Por isso, os docentes devem nortear-se de estratégias nas aulas de histórias que auxiliem numa melhor assimilação, acarretando assim, em indivíduos críticos reflexivos dos contextos que Ihes circundam. As aulas de história enfrentam ainda, uma postura de estagnação em relação a transmissão de seus conteúdos,visto que o que é mais evidenciado é a exatidão de fatos, datas, em detrimento da investigação que os alunos podem fazer dos períodos que thes constituem. Corrobora-se assim, a relevância de propor meios exitosos, como a Tecnologia, visionando aulas prazerosas e regidas pelo dinamismo dos conteúdos apresentados. 


\section{REFERÊNCIAS}

AOKI, Jane Maria Nóbrega. As tecnologias de informação e comunicação na formação continuados professores. EDUCERE, Revista da Educação, p.43-54, vol. 4, n.1, jan./jun., 2004. Disponível em: <http://revistas.unipar.br/educere/article/viewFile/181/155>. Acesso em: 10 jul. 2018.

BACICH, Lilian et al. Ensino Híbrido: Personalização e tecnologia na educação. Porto Alegre: Penso, 2015. 270 p.

BEZERRA, Holien Gonçalves; LUCA, Tania Regina de. Em busca de qualidade PNLD HISTÓRIA - 1996. Sposito, Maria Encarnação Beltraão (Org). Livros didáticos de Geografia e história: avaliação e pesquisa. São Paulo: Cultura Acadêmica, 2006. P.16 a 27.

BEHRENS, Marilda Aparecida. Projetos de aprendizagem colaborativa num paradigma emergente. MORAN, José Manuel; MASETTO, Marcos Tarciso.In: Novas Tecnologias e Mediação Pedagógica. 6. ed. Campinas, São Paulo: Papirus, 2008.

BRAGA, Denise Bértoli. Ambientes Digitais: reflexões teóricas. São Paulo: Cortez, 2013.

BRASIL, Ministério da Educação, (1997). Parâmetros Curriculares Nacionais para o Ensino Fundamental. Brasília, MEC/SE.

BRITO, G. da; PURIFICAÇÃO, I. da. Educação e novas tecnologias: um repensar. 2. ed. rev. atual. Curitiba: Ibex, 2008.

CARVALHO, Alexandre Sunaga e Camila Sanches de et al. As tecnologias Digitais no Ensino Híbrido. In: BACICH, Lilian; TANZI NETO, Adolfo; TREVISANI, Fernando de Melo. Ensino Híbrido. Porto Alegre: Penso, 2015. Cap. 7. p. 141-142.

CASTELLS, M. A sociedade em rede. A era da informação: economia, sociedade e cultura. São Paulo: Paz e Terra, 2011. Volume 1.

CERVO, A. L. BERVIAN, P. A. Metodologia científica. 5.ed. São Paulo: Prentice Hall, 2002.

ÉPOCA NEGÓCIOS: Tempo gasto com celular preocupa adolescentes e pais, mostra pesquisa. Brasil: Agencia Brasil, 28 ago. 2018. Disponível em: <https://epocanegocios.globo.com>. Acesso em: 22 nov. 2018.

FERREIRA, Marieta de Moraes; FRANCO, Renato. Aprendendo História: reflexão e ensino. São Paulo: Editora do Brasil, 2009. 
FREIRE, P. Professora SIM tia NAO. Cartas a quem ousa ensinar. São Paulo: Olho D’água, 1993.

GIL, Antônio Carlos. Como Elaborar Projetos de Pesquisa. 4. ed. São Paulo: Atlas, 2002.

GOMES, N. G. Computador na escola: novas tecnologias e inovações educacionais. In: BELLONI, M.L (Org.). A Formação na Sociedade do Espetáculo. São Paulo: Loyola, 2002, p. 119-134.

GOODSON, Ivor. Currículo, narrativa e o futuro social. Revista Brasileira de Educação. v. 12, n. 35, 2007.

GONZAGA, Amarildo Menezes. IN: PIMENTA, Selma Garrido; GHEDIN, Evandro; FRANCO, Maria Amélia Santoto. Pesquisa em educação: alternativas investigativas com objetos complexos. São Paulo. Ed. Loyola, 2006.

HOFFING, M. A. Z. As páginas de História. Cad. Cedes. Volume 23. Número 60. Campinas:2003. Disponível em: <http://www.scielo.br/scielo.php?pid=s010132622003000200005\&script=sci_arttext>. Acesso em: 09 jul. 2018.

KALINKE, Marco Aurélio. Para não ser um Professor do Século Passado. Curitiba: Gráfica Expoente, 1999.

KENSKI, Vani Moreira. Tecnologias e ensino presencial e a distância. Campinas: Papirus, 2004.

KEMMIS e MC TAGGART, 1988, apud Elia e Sampaio, 2001, p.248.

LAVILLE, C.; DIONNE, J. A construção do saber: manual de metodologia dapesquisa em ciências humanas. Belo Horizonte: UFMG, 1999.

LEMOS, Silvana. Nativos Digitais $\mathbf{x}$ aprendizagens: um desafio para a escola. Senac, Rio de Janeiro, 2009 v.35, n.3, 9 de out/2018.

LÉVY, P. As tecnologias da inteligência: o futuro do pensamento na era da informática. Carlos Irineu da Costa (trad.). 2. ed. São Paulo: Editora 34, 2010.

LIMA, Leandro Holanda Fernandes de; MOURA, Flavia Ribeiro de. O professor no Ensino Híbrido. In: BACICH, Lilian; TANZI NETO, Adolfo; TREVISANI, Fernando de Melo. Ensino Híbrido: Personalização e tecnologia na educação. Porto Alegre: Penso, 2015. Cap. 4. p. 89-102.

LOPES, Kaique Moreira Léo; MONTEIRO, Rafael Brito (Ed.). As tics no ensino de história - A educação em conformidade com o Mercado.The icts in history teaching - The education in accordance with the market. Redvista Latino-americana de História, Unisinos, v. 5, n. 15, p.236-251, 16 mar. 2016.

LUCKESI, C. C. Avaliação da aprendizagem escolar. 21. ed. São Paulo: Cortez, 2010. 
MAGALHÃES, M. de S. História e cidadania: por que ensinar história hoje? In: ABREU, M.; SOIHET, R. (Org). Ensino de história: conceitos, temáticas e metodologia. Rio de Janeiro: Casa da palavra, 2003.

MALHOTRA, N. Pesquisa de marketing. 3. ed. Porto Alegre: Bookman, 2001.

MARCONI,

M.

A;LAKATOS,E.M.Técnicasdepesquisa:planejamentoeexecuçãodepesquisas, amost ragens e técnicas de pesquisas, elaboração reinterpretação de dados. 3. ed. São Paulo: Atlas, 1996.

MORAES, M. C. Informática educativa no Brasil: um pouco de história. Em Aberto, Brasília, ano 12, n. 57, jan.-mar. 1993.

MÓRAN, José Manuel. Formação de educadores para uma nova escola. In Educação digital e tecnologias da Informação e da comunicação. Salto para o Futuro, TV Escola, Ano XVII, botetim18, set/out, 2008, p. 43-47.

. Educação Híbrida: Um conceito-chave para a educação, hoje. In: BACICH, Lilian; TANZI NETO, Adolfo; TREVISANI, Fernando de Melo. Ensino Híbrido: Personalização e tecnologia na educação. Porto Alegre: Penso, 2015. Cap. 1. p. $27-45$.

MORIN. Transdisciplinaridade e educação do futuro. Jornal APASE. São Paulo, ano XII, v. 92, jul., pp. 11-12, 2001.

NASCIMENTO, Maria Alessandra Nascimento Dubowski. A experiencia da Escola Municipal Prof ${ }^{\underline{a}}$ Coraly De Sousa Freire: Qual a relação entre o espaço e o processo de ensino e aprendizagem? In: BACICH, Lilian; TANZI NETO, Adolfo; TREVISANI, Fernando de Melo. Ensino Híbrido: Personalização e tecnologia na educação. Porto Alegre: Penso, 2015. p. 121-122.

PALFREY, John; GASSER, Urs. Nascidos na era digital: entendendo a primeira geração dos nativos digitais. Porto Alegre:Artmed, 2011.

PISCHETOLA, Magda. Inclusão Digital e Educação: A nova cultura da sala de aula. Rio de Janeiro: Vozes, 2016.

POZO. POSTIGO, Y. Los procedimientos como contenidos escolares: uso estratégico de la información. Barcelona: Edebé, 2000.

Adquisición de conocimiento: cuando la carne se hace verbo. Madrid: Morata, 2003.

RICHARDSON, R. J. Pesquisa Social: métodos e técnicas. 3. ed. 8. Reimpr. São Paulo: Atlas, $2008.334 \mathrm{p}$.

RODRIGUES, Eric Freitas. A Avaliação e a Tecnologia: A questão da verificação da aprendizagem no modelo de ensino híbrido. In: BACICH, Lilian; TANZI NETO, 
Adolfo; TREVISANI, Fernando de Melo. Ensino Híbrido: Personalização e tecnologia na educação. Porto Alegre: Penso, 2015. Cap. 6. p. 123-137.

Rodriguez, C. L. (2011). A utilização de recursos audiovisuais em comunidades virtuais de aprendizagem: potencialidades e limites para comunicação e construção de conhecimentos em rede. Tese (Doutorado em Artes) - Programa de Pós-Graduação em Artes, Universidade Estadual de Campinas, Campinas. Disponível em: Acesso em: 02 set. 2018.

ROUSSEAU, Jean-Jacques. Do Contrato Social. Coleção A Obra Prima de Cada Autor. São Paulo: Editora Martin Claret, 2003.

RUDIO, F. V. Introdução ao projeto de pesquisa cientifica. 4. ed. Petrópolis: Vozes, 1980.

SALGADO, Maria Umbelina Caiafa. Formação de Professores: um grande desafio. In: Boletim do Salto para o Futuro. Brasília: MEC, SEED, 2003. Disponível em:<http: // www.tvebrasil.com.br/ salto/ boletins2003/detext2>. Acesso em: 28 dez. 2018.

SANTOS, Glauco de Souza. Espaços de Aprendizagem. In: BACICH, Lilian; TANZI NETO, Adolfo; TREVISANI, Fernando de Melo. Ensino Híbrido. Porto Alegre: Penso, 2015. Cap. 5. p. 103-120

SILVA, M. d. Como se ensina e como se aprende a ser professor: a evidência do habitus professoral e da natureza prática da didática. Bauru, São Paulo: Edusc, 2003.

SILVA, Marco; PORTO, Amélia. Nas trilhas do Ensino de História: Teoria e Prática Anos Iniciais do Ensino Fundamental Regular. Belo Horizonte: Rona, 2012. 128 p.

TARDIF, M. Saberes docentes e formação profissional. 3. ed. Petrópolis: Vozes, 2014

TEIXEIRA, Anísio. Educação e Mundo Moderno. Rio de Janeiro: Editora da UFRJ, 1997.

THIOLLENT, Michel. Metodologia de pesquisa-ação. 15. ed. São Paulo: Cortez,2007.

TORRES, Cláudio. A Bíblia do Marketing Digital. São Paulo: Novatec editora Ltda., 2009.

TORNAGHI, Alberto. Escola e tecnologia: uma conversa. Programa Salto para o Futuro. In: Boletim da Série Escola faz tecnologia faz escola... Brasília: MEC, SEED, 2003. Disponível em: Acesso em: 31 jul. 2010.

TREVISANI, Fernando. Ensino Híbrido, o que é e como utilizá-lo? Desvendando o Ensino Hibrido. 2015. Disponível em: <https://silabe.com.br/blog/ensino-hibrido-oque-e/>. Acesso em: 30 out. 2018. 
VALENTE, José Armando. Prefácio: O Ensino Híbrido veio para ficar. In: $\mathrm{BAClCH}$, Lilian; TANZI NETO, Adolfo; TREVISANI, Fernando de Melo. Ensino Híbrido: Personalização e tecnologia na educação. Porto Alegre: Penso, 2015. p. 14-17.

VIEIRA, Maria Alexandra Nogueira. Educação e sociedade da informação: Uma perspectiva crítica sobre as TIC num contexto escolar. 2003. Disponível em: 58 https://repositorium.sdum.uminho.pt/bitstream/1822/3276/1/Tese_Educacao_Socied ade_Informacao_AV.pdf. Acesso em: 15. jul. 2018.

TECNOLOGIAS de informação e comunicação. Wikipédia. Disponível em:<http://pt. wikipedia.org/w/index.php?title=Conteúdo aberto\&oldid=1569600 > .

Acesso em: data: 23 dez 2018.

XAVIER, Antonio Carlos. Como fazer e apresentar trabalhos científicos em eventos acadêmicos: ciências humanas e socais aplicadas: artigo, resumo, resenha, monografia, tese, dissertação, tcc, projeto, slide - Recife: Editora Rêspel, 2012.

ZABALZA, M. A. Didática de la educácion infantil. Madrid: Narcea, 1987.

ZUCCHI, Bianca. 0 ensino de História nos anos iniciais do Ensino Fundamental: teoria, conceitos e uso de fontes. São Paulo: Sm, 2012. 160 p. 


\section{APÊNDICES}




\section{APENDICE A - TERMO DE CONSENTIMENTO LIVRE E ESCLARECIDO}

Você está sendo convidado(a) para participar da pesquisa sobre:A INSERÇÃO DAS TECNOLOGIAS DE INFORMAÇÃO E COMUNICAÇÃO NA APRENDIZAGEM DO ENSINO DE HISTÓRIA DOS ALUNOS DA U.E.F. BALBINA CARVALHO, temática de estudo para a conclusão do curso de Licenciatura Plena em Pedagogia da Universidade Estadual do Maranhão (UEMA).

A qualquer momento você pode desistir de participar e retirar seu consentimento. Sua recusa não trará nenhum prejuízo em relação aos pesquisadores ou com a instituição.

As informações obtidas através dessa pesquisa serão confidenciais, e asseguram o sigilo sobre sua participação e o nome da instituição. Os dados não serão divulgados de forma a resguardar sua identificação.

Bacabal-MA,

Sujeito da pesquisa

Érica Cristina Frazão de Moura

Laise Katiane Alencar Lima 


\section{APÊNDICE B - TERMO DE CONSENTIMENTO LIVRE E ESCLARECIDO AOS PAIS}

Seu filho(a) está sendo convidado(a) a participar da pesquisa:A INSERÇÃO DAS TECNOLOGIAS DE INFORMAÇÃO E COMUNICAÇÃO NA APRENDIZAGEM DO ENSINO DE HISTÓRIA DOS ALUNOSA DA U.E.F BALBINA CARVALHO.

Os objetivos deste estudo consistem em sensibilizar os educandos acerca das tecnologias na aprendizagem de história. Caso você autorize, seu filho irá participar desse estudo. A participação dele(a) não é obrigatória e, a qualquer momento, poderá desistir da participação. Tal recusa não trará prejuízos em sua relação com o pesquisador ou com a instituição em que ele estuda. Tudo foi planejado para minimizar os riscos da participação dele(a), porém se ele(a) (especificar riscos, ex: sentir desconforto com as perguntas, dificuldade ou desinteresse) poderá interromper a participação e, se houver interesse, conversar com o pesquisador sobre o assunto.

Você ou seu filho(a) não receberá remuneração pela participação. A participação dele(a) poderá contribuir para um melhor desempenho dos seus filhos nas aulas de história com os dispositivos tecnológicos. As suas respostas não serão divulgadas de forma a possibilitar a identificação. Além disso, você está recebendo uma cópia deste termo onde consta o telefone do pesquisador principal, podendo tirar dúvidas agora ou a qualquer momento.

Eu, declaro

que entendi os objetivos, riscos e benefícios da participação do meu filho(a) sendo que:

) aceito que ele(a) participe ( ) não aceito que ele(a) participe

Bacabal-MA, 1

Érica Cristina Frazão De Moura

Laise Katiane Alencar Lima 


\section{APÊNDICE C - QUESTIONÁRIO PARA OS DISCENTES}

1) Tem acesso à internet?

( ) Sim

( ) Não

2) Que meios você utiliza para esse acesso?

( ) Celular android

( ) Tablet

( ) Computador

( ) Mais de um desses itens

( ) Nenhum

3) Sabe conceituar as TICs?

( ) Sim

( ) Não

4) A professora utiliza as TICs nas aulas de história?

( ) Não

( ) Com frequência

( ) Raras as vezes

5) Os conteúdos de história tornam-se mais claros quando se utilizam algum recurso tecnológico?

( ) É mais fácil assimilar com eles

( ) Não contribuem em nada

( ) Só servem para passar o tempo

6) Quando a professora solicita a pesquisa de temas de história, você recorre a internet?

( ) Nunca

( ) Sempre

( ) Só quando a professora manda

7) Se utiliza a internet limita-se a apenas o primeiro site que vê para finalizar a pesquisa?

( ) Vejo só o primeiro

( ) Abro vários

( ) Não pesquiso sites dos conteúdos de história 
8) Costuma assistir vídeos, músicas e filmes sobre os conteúdos de história?

( ) Sempre

( ) Nunca

( ) Só se a professora solicitar

( ) Só se ela colocar na sala de aula

9) A professora utiliza o laboratório de informática nas aulas de história?

( ) Sempre

( ) Nunca

( ) Não há laboratório

10) Antes do projeto a Inserção das TICs no ensino aprendizagem de história já tinha escutado ou lido sobre as TICs?

( ) Sim

( ) Não

11) As aulas com o uso das TICs feitas pelo projeto deixaram as aulas de histórias mais prazerosas?

( ) Não

( ) Continuaram do mesmo jeito

( ) Foi mais interessante aprender história com elas

12) As TICs nas aulas de história facilitam uma apreensão mais ampla pelos conteúdos tratados em sala de aula?

( ) Não

( ) Os conteúdos pareciam mais reais

( ) Os conteúdos tornaram-se mais divertidos com elas

13) Utilizam as TICs para revisar ou complementar os conteúdos de história após o projeto?

( ) $\operatorname{Sim}$

( ) Não 
ANEXOS 
Imagem 1 - Pesquisadoras apresentando as TICs

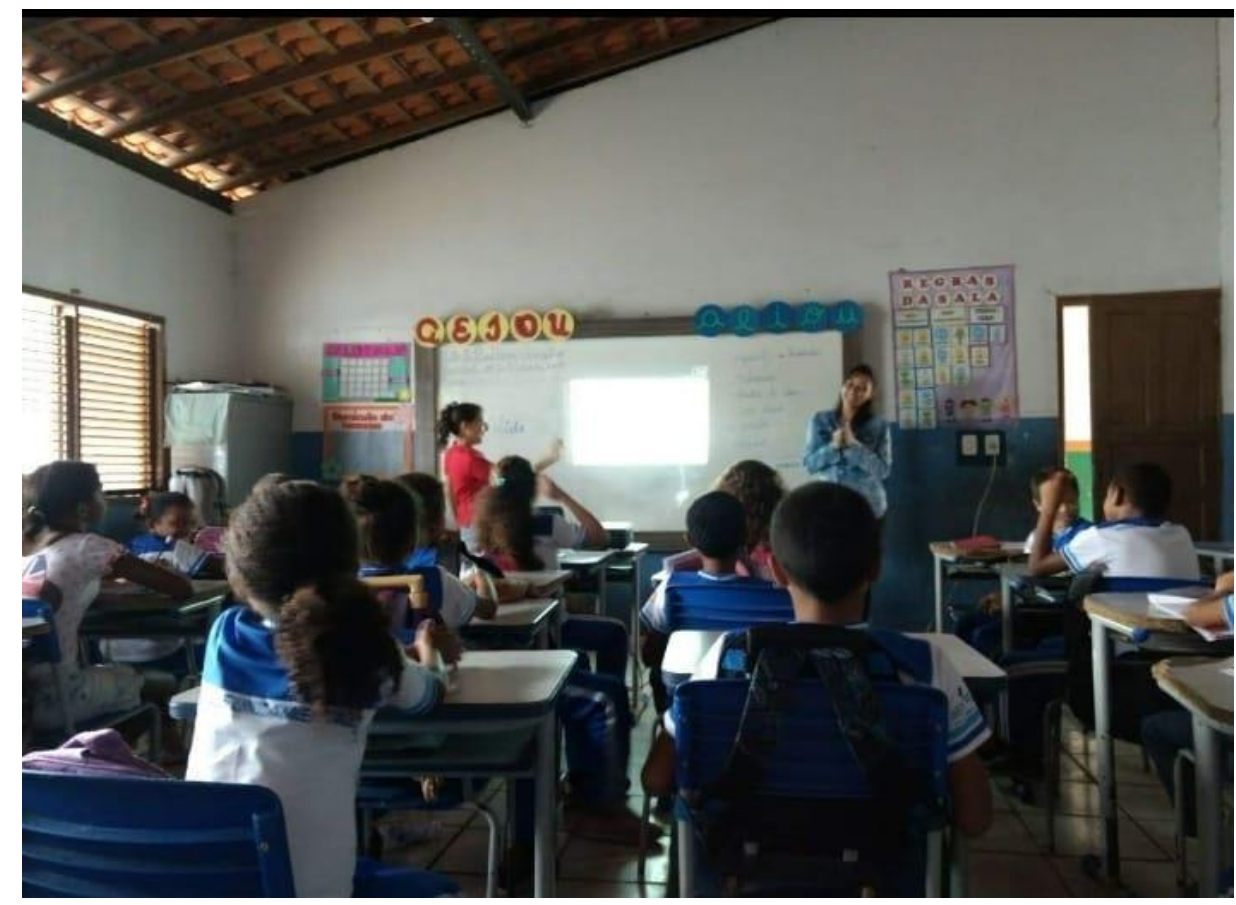

Fonte: Elaboração própria (2018).

Imagem 2 - Exemplos de TICs

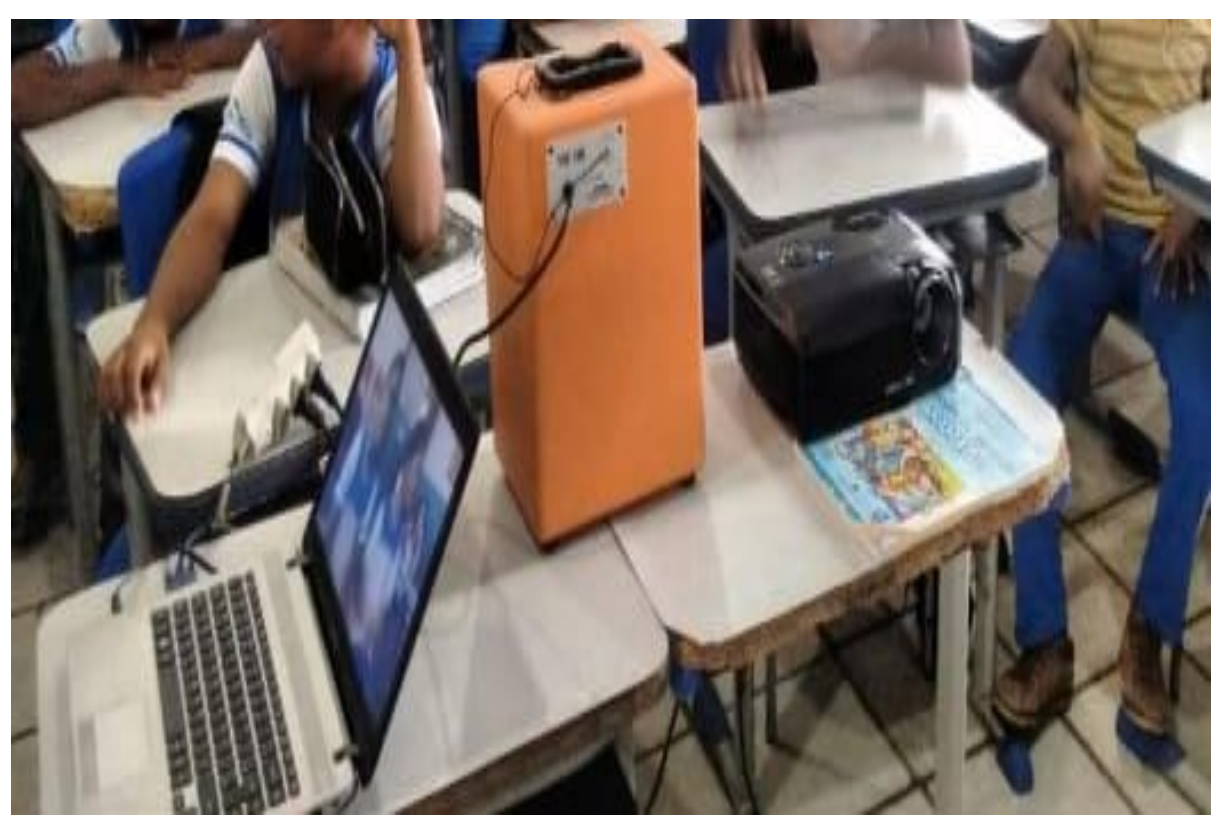

Fonte: Elaboração própria (2018). 
Imagem 3 - Alunos elaborando slides dos conteúdos de história

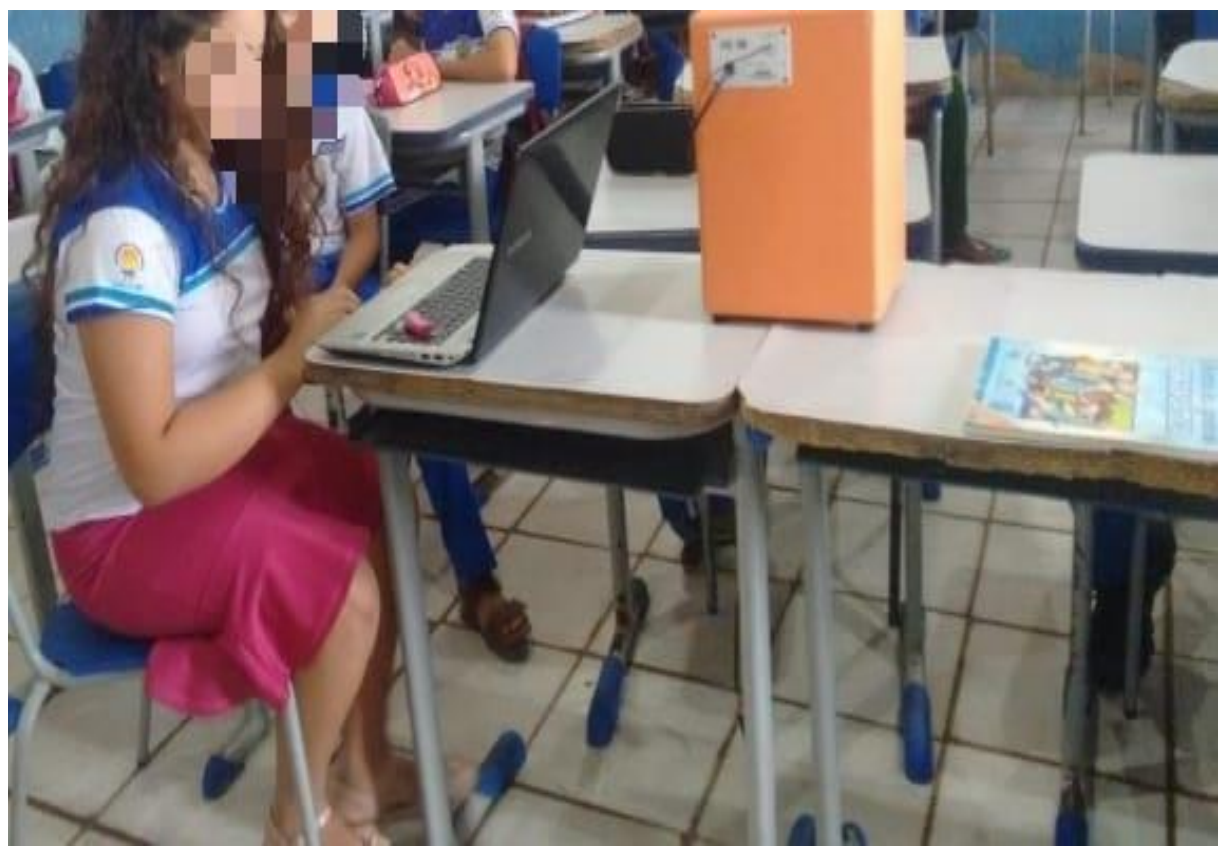

Fonte: Elaboração própria(2018).

Imagem 4 - Pesquisadoras associando as novelas nos temas de história

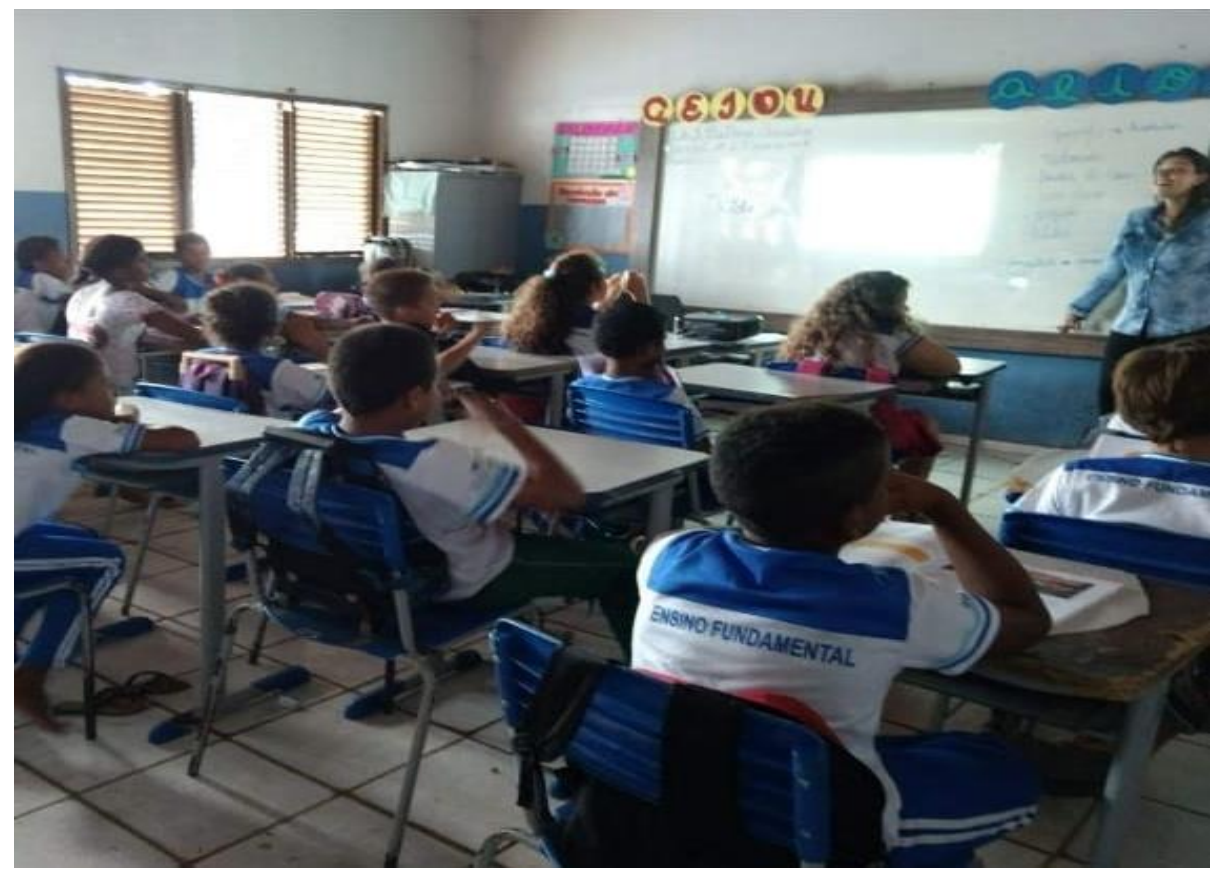

Fonte: Elaboração própria (2018). 
Imagem 5 - Aplicação de questionário com os discentes

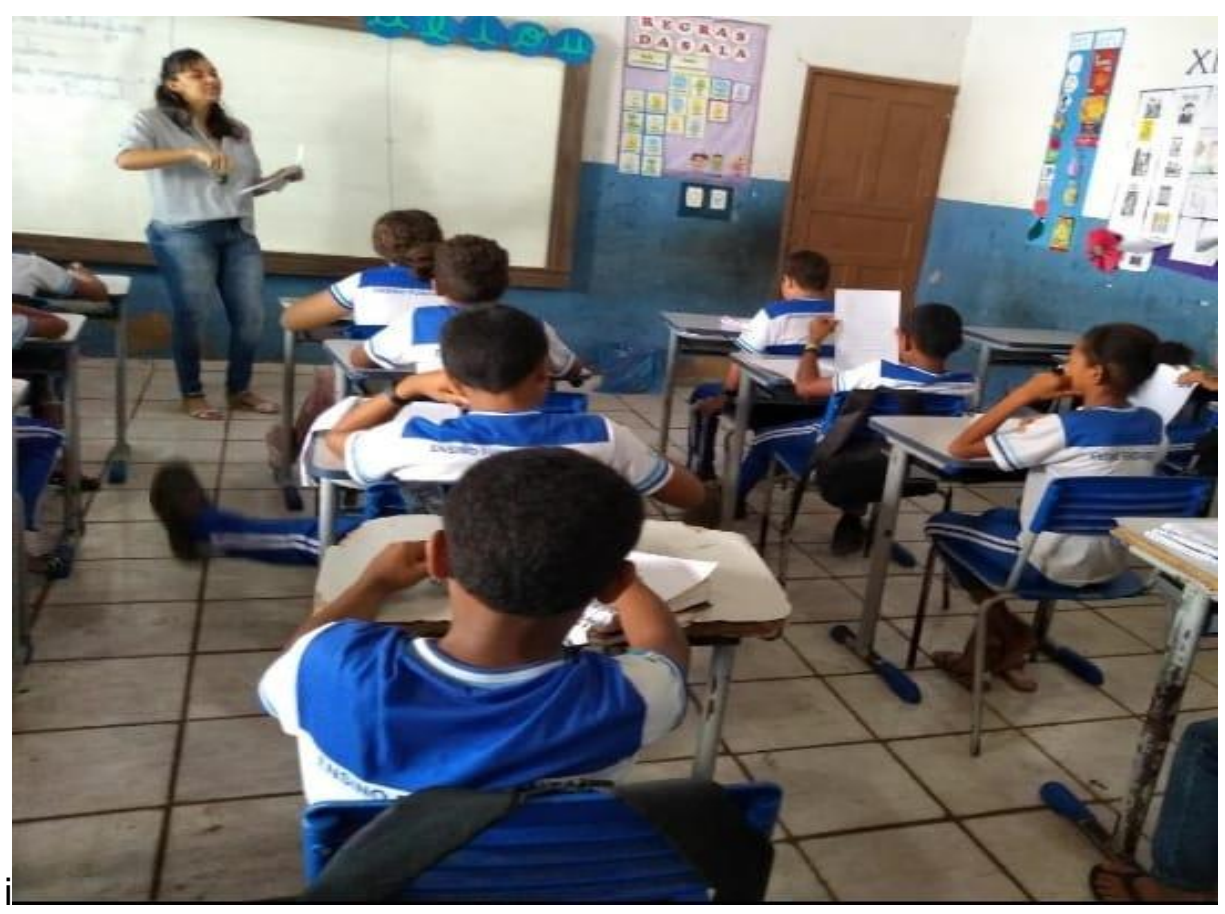

Fonte: Elaboração própria (2018). 